\title{
BURNING ALT-WARTENBURG. ARCHAEOLOGICAL EVIDENCE FOR THE CONFLICTS BETWEEN THE TEUTONIC ORDER AND THE GRAND DUCHY OF LITHUANIA FROM A DESERTED MEDIEVAL TOWN NEAR BARCZEWKO (WARMIA, POLAND)
}

\author{
FELIX BIERMANN${ }^{1}$ CHRISTOFER HERRMANN² ${ }^{2}$ ARKADIUSZ KOPERKIEWICZ ${ }^{3}$, \\ EDVINAS UBIS ${ }^{4}$
}

\footnotetext{
${ }^{1}$ Greifswald University, Historical Institute, Domstr. 9, D-17487 Greifswald, e-mail: felix.biermann@uni-greifswald.de

${ }^{2}$ Gdańsk University, Historical Department, Institute of History of Arts, ul. Bielańska 5, 80-851 Gdańsk, e-mail: chriherr@yahoo.de

${ }^{3}$ Gdańsk University, Historical Department, Institute of Archeology and Ethnology, ul. Bielańska 5, 80-851 Gdańsk, e-mail: arekoper@poczta.onet.pl

${ }^{4}$ Klaipedda University, Institute of Baltic Region History and Archaeology, Herkaus Manto str. 84, 92294 Klaipeda,

e-mail: edvinas.ubis@gmail.com
}

In the $14^{\text {th }}$ century, the Teutonic Order and the Grand Duchy of Lithuania engaged in severe armed conflicts whose central element was raids on enemy territory. Since nearly all written evidence was authored by one side in the conflict, the chroniclers of the Order, the reliability of the reports in respect to violence and cruelties is not clear. Therefore, archaeological discoveries are of great importance for understanding these wars and their reality. An instructive example is the deserted town of Alt-Wartenburg in Warmia (Barczewko near Olsztyn, Northeast Poland), which was captured and destroyed in 1354 by a Lithuanian army and afterwards abandoned. Recent research has revealed considerable traces of the town's violent end: burnt houses, weapons, skeletons of the victims, and other traces of ravages and violence. The site and the finds are discussed against the background of the written record, the warfare of its time and region, and other archaeological witnesses of this period.

Keywords: Wars of Teutonic Order and Grand Duchy of Lithuania; conflict archaeology; Middle Ages; deserted town; Warmia.

Plačiausiai ir geriausiai žinomas Lietuvos Didžiosios Kunigaikštystès istorijos etapas yra kovos su Vokiečiu ordinu. Intensyviausios vyko XIV a. Vienu svarbiausiu šiu kovų elementu tapo plèšiamieji ir siaubiamieji žygiai priešo teritorijoje. Šiame straipsnyje yra nagrinèjami archeologiniai Varmijos Alt Vartenburgo (Baczewko) miesto (prie Olštyno, Šiaurès rytų Lenkija) duomenys, puikiai atskleidžiantys Lietuvos kariuomenès antpuolio pasekmes ir pobüdị.

Istoriniai šaltiniai rodo, kad miestas buvo užpultas ir sunaikintas $1354 \mathrm{~m}$. ir šioje vietoje nebebuvo atkurtas. Archeologiniu tyrimu metu buvo surinkta daugybe duomenu: sudegusių namu fragmentu, ginklu, žuvusiujų kūnu palaiku ir kitu su miesto sunaikinimu susijusių radinių. Šie duomenys nagrinejjami rašytiniu šaltinių, karybos ir archeologiniame kontekste, siekiant parodyti kraupias tokiu antpuoliu pasekmes ir pobūili.

Reikšminiai žodžiai: Lietuvos ir Vokiečių ordino karas; konfliktų archeologija; viduramžiai; apleistas miestas; Varmija. 


\section{INTRODUCTION}

The Teutonic Order fought gruelling wars with the Grand Duchy of Lithuania in the $14^{\text {th }}$ century: the pagan regime was the Order's main opponent. Each year, the Teutonic Knights, supported by nobles from the Holy Roman Empire and other European countries on a 'Prussian pilgrimage' or 'Lithuanian pilgrimage', attacked in crusader campaigns in Lithuanian territory, mainly against Samogitia (Žemaitija), but without being able to defeat the opponent. Lithuania's Grand Dukes responded with military assaults in the territory of the Order and its associated bishoprics, also without decisive success. The warfare of both sides in this 'hundred year war' (Housley 1992, p. 338; Pósán 2014, p. 51) was characterised, according to written sources, mainly by looting and arson, the taking of captives, and slaughters in enemy territory (Boockmann 1981, pp. 151-169; Paravicini 1989/1995; Gudavičius 2001, pp. 73-79; Trupinda 2009, p. 23; Pósán 2014, pp. 5152; Herrmann 2015, pp. 14-15). However, the written sources of the German chroniclers involved in the conflict are uncertain in respect to their reliability: they definitely exaggerated the cruelties to blame the enemy, badmouth the pagans, and support the Christian approaches. What are the true facts of the matter?

Archaeological finds and features contribute to that question, delivering 'neutral' witnesses of military events, for instance of attacks on towns or castles. The research in the deserted town of Alt-Wartenburg near the village of Barczewko not far from Allenstein (Olsztyn, Warmia-Masuria
Voivodeship, Northeast Poland) offers outstanding archaeological insights into the reality of these violent times. Alt-Wartenburg (Wartenburg at that time $)^{1}$ was founded in the 1320 s by the bishop of Ermland (Warmia) and was destroyed in the course of a Lithuanian raid in 1354. Because the town was rebuilt afterwards at another place (the still extant town of Barczewo), the remains of the first town have remained well preserved since the day of its destruction. A joint Polish-German 2013-2019 research project, supported by a Lithuanian team in the summer $2018,{ }^{2}$ provided insights into the conquest and violent extinction of the settlement during that event. The Alt-Wartenburg findings are presented and contextualised here against the background of the history of the town, the GermanLithuanian conflicts, and the Lithuanian warfare of that time.

\section{THE HISTORY AND ARCHAEOLOGY OF ALT-WARTENBURG}

Ermland Diocese consisted, at its southeast edges, of sparsely populated, densely forested areas contemporarily termed große Wildnis (the great wilderness) (Szorc 1990; Herrmann 2015, pp. 12, $20-$ 21). Beginning in the $1280 \mathrm{~s}$, this region was colonised step by step. The castle and town of Alt-Wartenburg were founded in that context in the 1320s, in the territory called Gunelauken in Northwest Galinden. The initiators and organisers were Eberhard von Neisse (d. 1326), bishop of Ermland, and his reeve, the Teutonic knight, Friedrich von Liebenzell (SRP I, pp. 192-193). The colonists probably came from

\footnotetext{
${ }^{1}$ The town was established under the name Wartenburg, the nearby village later taking the name Alt-Wartenburg to differentiate it from newly founded Wartenburg, approximately $6 \mathrm{~km}$ away (the still extant town of Barczewo); for this reason the name of Alt-Wartenburg was used for the site of the first town.

2 The Polish-German research project 'Alt-Wartenburg / Barczewko - das ermländische Pompeji', was funded by the Bundesbeauftragte für Kultur und Medien (Bonn) and supported by the Universities of Gdańsk, Göttingen, and Greifswald, the town of Barczewo, and the Historischer Verein für Ermland. In August 2018, all the authors of this paper cooperated in the investigation of the site of Alt-Wartenburg, together with Polish, Lithuanian, and German students. The project will be continued.
} 


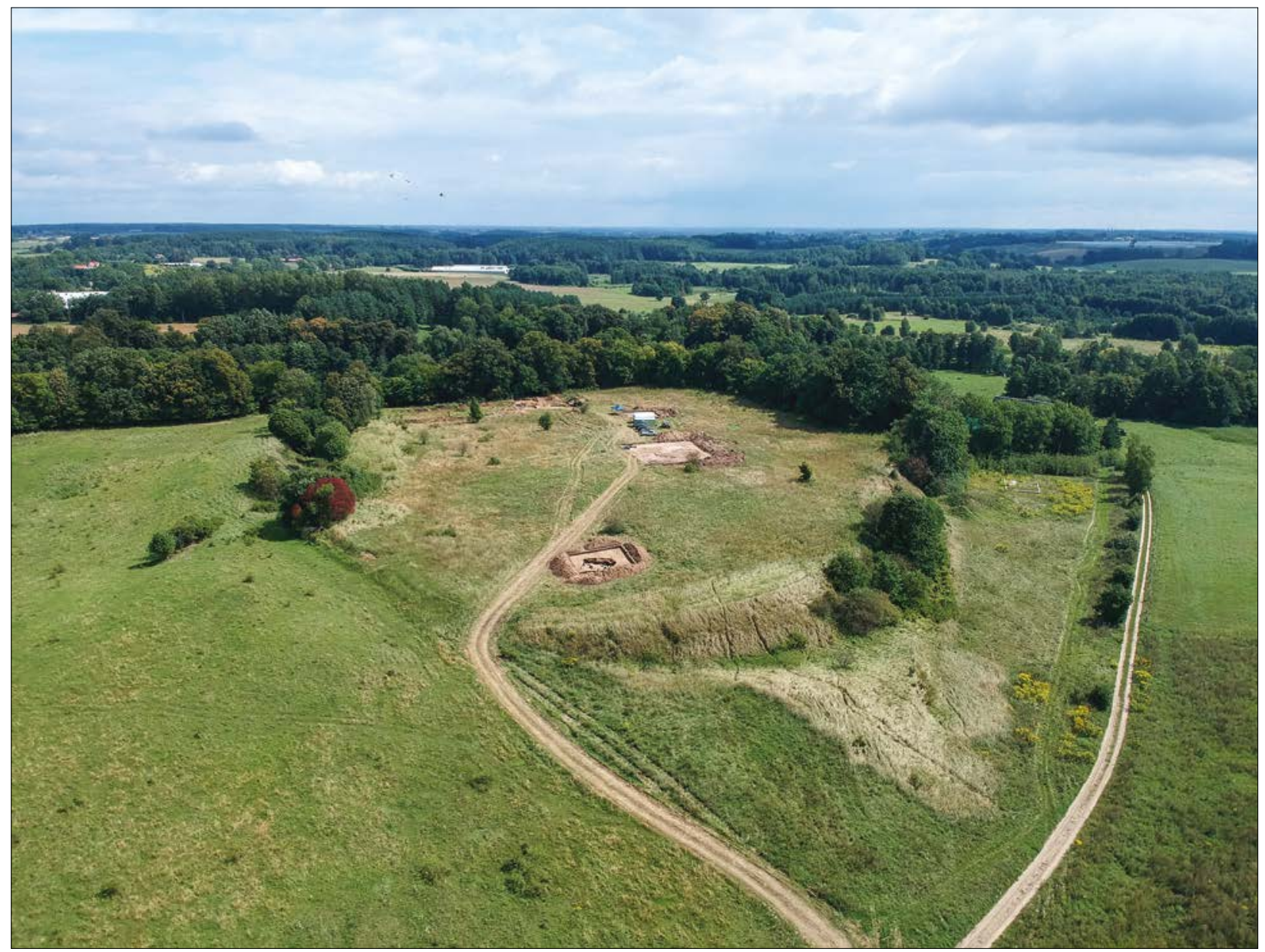

Fig. 1. The deserted town of Alt-Wartenburg (Barczewko). 2018 aerial view of the site from the west showing the rampart and excavation trenches. Photo by L. Plith Lauritsen.

Silesia (Röhrich 1916; Riemann 1965). The castle was definitely not far from the town, but it has yet to be located; it perhaps was built $1.6 \mathrm{~km}$ to the east at the site of a former Prussian hill fort called Wachthügel (Guard Hill) or Schlossberg (Castle Hill) prior to 1945 (Klimek 2008, pp. 216-217; 2013, pp. 214-216, Figs. 16, 17), but this has not been confirmed. In any case, in the textual record the castle is eclipsed in the following years by the town and not mentioned again after 1325 .

The urban settlement, however, initially developed satisfactorily, according to some written sources and the archaeological evidence. But in 1354, Herald Wigand von Marburg, a contemporary chronicler of the German-Lithuanian conflicts, reported that Lithuanian Grand Dukes Kęstutis (d. 1382) and Algirdas (d. 1377) captured the town, capturing and probably killing all the inhabitants (SRP II, p. 520; von Bönigk 1883; Szorc 1990, p. 166; Klimek 2008, pp. 214-217): 'In 1354 Kęstutis and Algirdas, along with their nobles etc., rushed to Wartenberg in the land of Gunelauken, which they destroyed in a hostile manner with fire, etc. and nobody escaped their hands' („Anno 1354 Kynstute, Algard cum bayoribus etc. festinant in Wartenberg in terram Gunelauken, quam hostili more, igne etc. devastant, et nemo evasit manus eorum' (Scriptores 1863, p. 520; Raczyński 1842, pp. 96-99). 


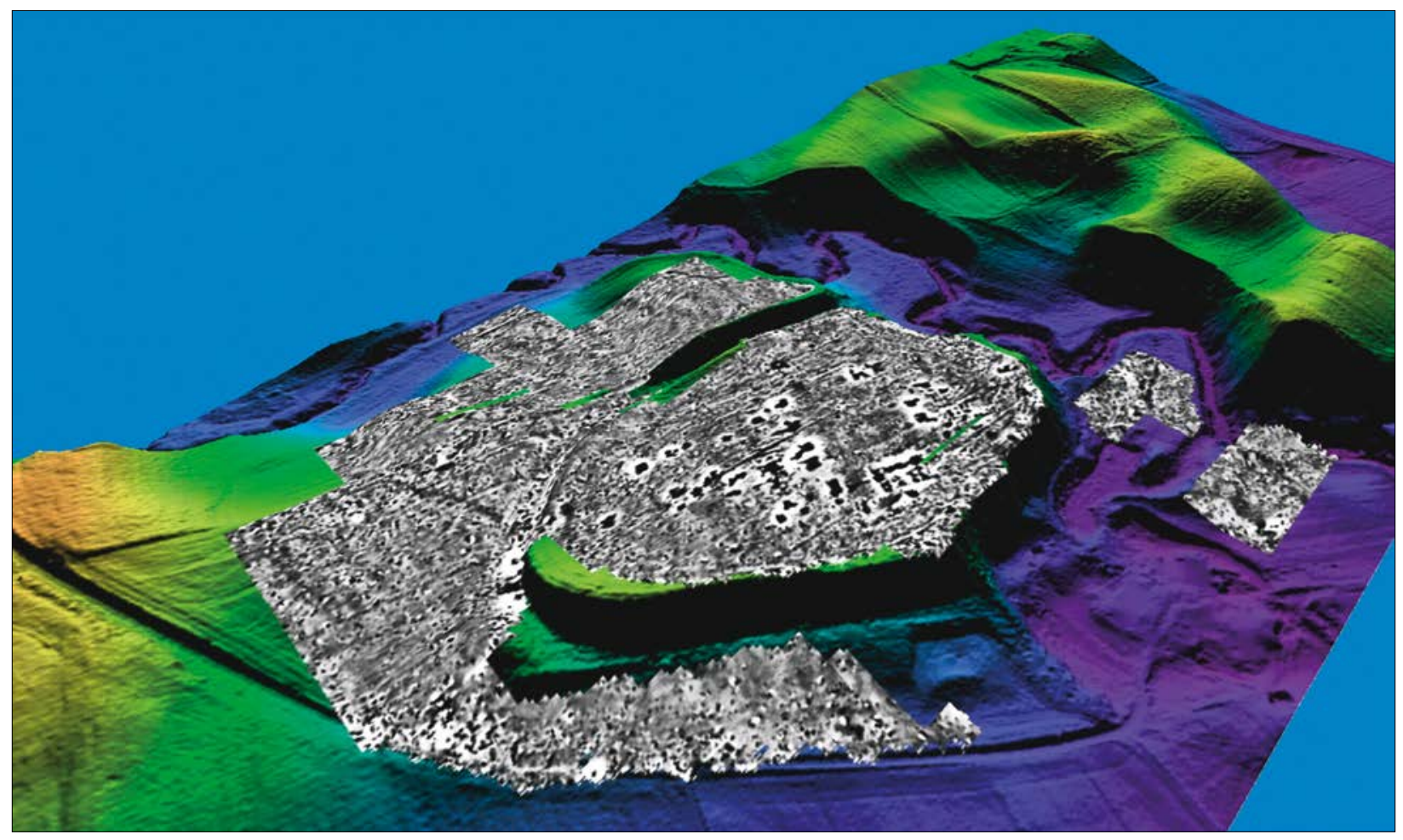

Fig. 2. The deserted town of Alt-Wartenburg (Barczewko). Digital terrain model (superelevated) on LIDAR base with a geomagnetic plan of the medieval town and its surroundings. Created by P. Wroniecki.

The deserted town (Figs. 1, 2) lies on a promontory $350 \mathrm{~m}$ northeast of a large body of water, Lake Wadąg. Its ramparts and moats form, due to the natural relief, a roughly $220 \times 160 \mathrm{~m}$ oval site. Aerial photos and geophysical discoveries indicate that parts of the surrounding area were enclosed with a ditch and also sparsely settled. The town was small but it had all the elements of an urban settlement: a central $40 \times 60 \mathrm{~m}$ rectangular market square bordered on three sides by house cellars and on the fourth, the south side, by a large, three-winged building complex, i.e. the town or market hall (mercatorium) (Fig. 3). Moreover, there was a regular road network with two main streets running parallel to each other from the market place to the west, while the northern row ended at the town gate. The fortifications consisted of strong ramparts, moats, and a gate, which last is still recognizable today as a depression in the bank's western remnants. A church and a cemetery were located in the northeast part of the town, in the regionally characteristic peripheral position. A bathhouse cum tavern operated at the town's east rampart and about two dozen houses stood alongside the market and streets. The town, which was professionally planned and surveyed from the beginning, was built on virgin soil in the vicinity of a rather sparsely populated Prussian settlement area (Klimek 2008). All of the buildings were made of wood or wood and loam in half-timber constructions. So far, bricks have been found only in the base of the bathhouse hearth. Before artificial stone became common in rather peripheral settlements, the town was destroyed. The 2013-2018 research confirmed the identification of the site, traditionally called Altstadt (Old Town) (von Bönigk 1883), with the first founding of Wartenburg: the finds show an urban environment with fashionable late Gothic clothing accessories, imported ceramics from Germany, and 


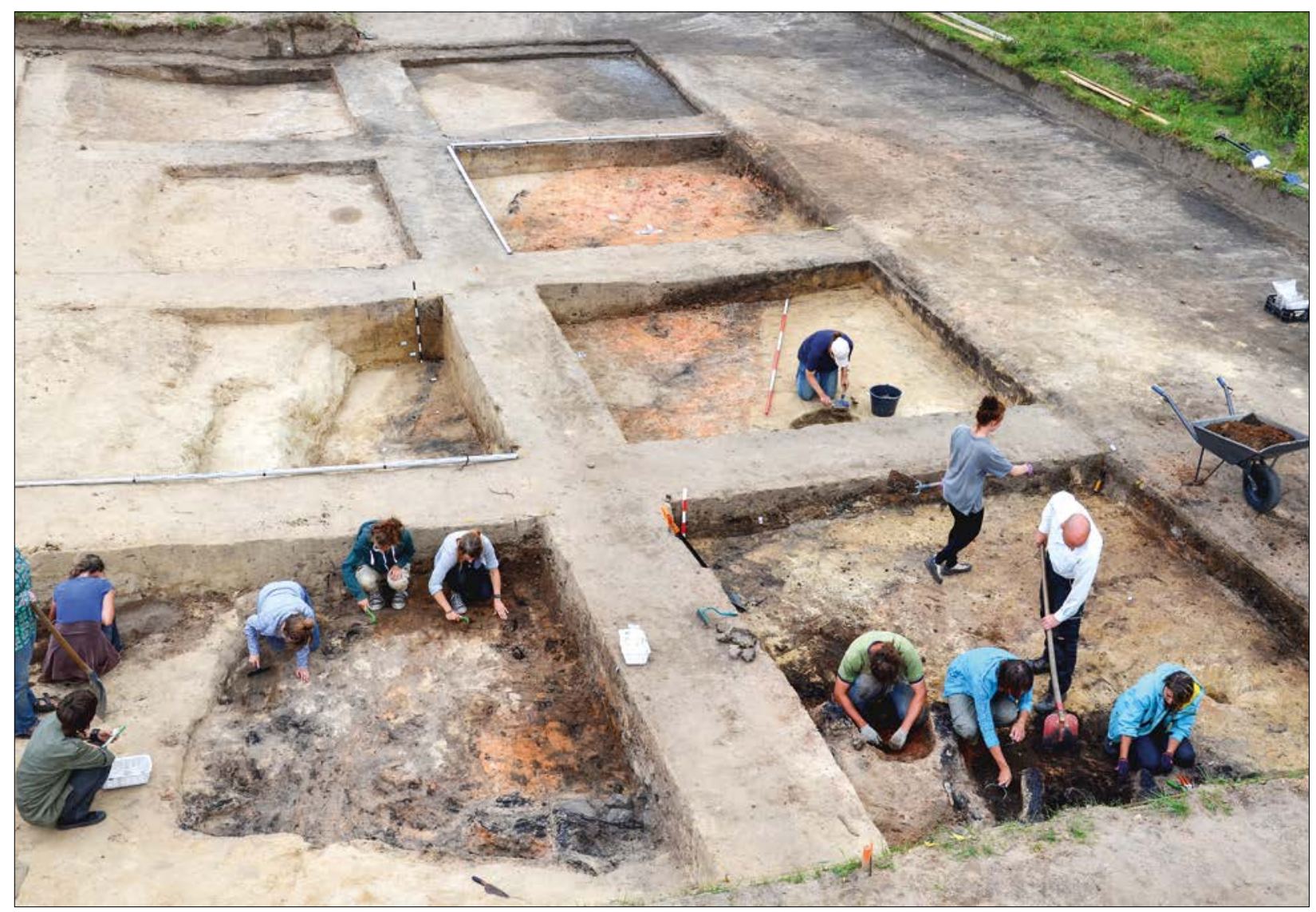

Fig. 3. The deserted town of Alt-Wartenburg (Barczewko). 2014 excavation in the mercatorium area showing the cellars and fire debris in the north and west wings. Photo by A. Koperkiewicz.

trade and craft-related finds. They were dated to an appropriate time span, especially by the silver coins (mainly from the Teutonic Order) and a multitude of dendrochronological data from burned timbers, the data from both the coinage and the tree rings being exclusively pre-1354 (see Biermann et al. 2016a; 2016b; 2018a; 2018b).

In the given context, the fortification was of special interest. In the east and west, the town was naturally protected by steep hill slopes; the excavations in this area produced the remnants of a low rampart, which probably had a palisade originally. In the north and west, especially on the very vulnerable west side where the land outside the town steadily rose to an elevation west of the town, massive fortifications had been constructed: a semi-circular rampart-ditch-fortification with a gate. The rampart and moat were investigated by a trench at its strongest part in the west. It had been a roughly $1.10 \mathrm{~m}$ high, $8 \mathrm{~m}$ wide rampart and $2.80 \mathrm{~m}$ deep, roughly $9 \mathrm{~m}$ wide, $\mathrm{V}$-shaped ditch. The moat held water at least temporary, as evidenced by the dark sediment on its bottom (Fig. 4). A plank fence or palisade definitely stood on the rampart, but no traces of it were recorded, which is not astonishing in view of the later erosion and disturbance through agrarian use. The moat's $\mathrm{V}$-shaped profile is unusual in the region, but parallels exist in the moats of High and Late Medieval towns in Northern Germany, for instance in Braunschweig and Hannover (Rieger 2010, p. 140, Fig. 101; Brückner 2016, p. 59) and at Late Medieval German castles (Schütz 2007, p. 330; Rosmanitz 2009); thus, it is 


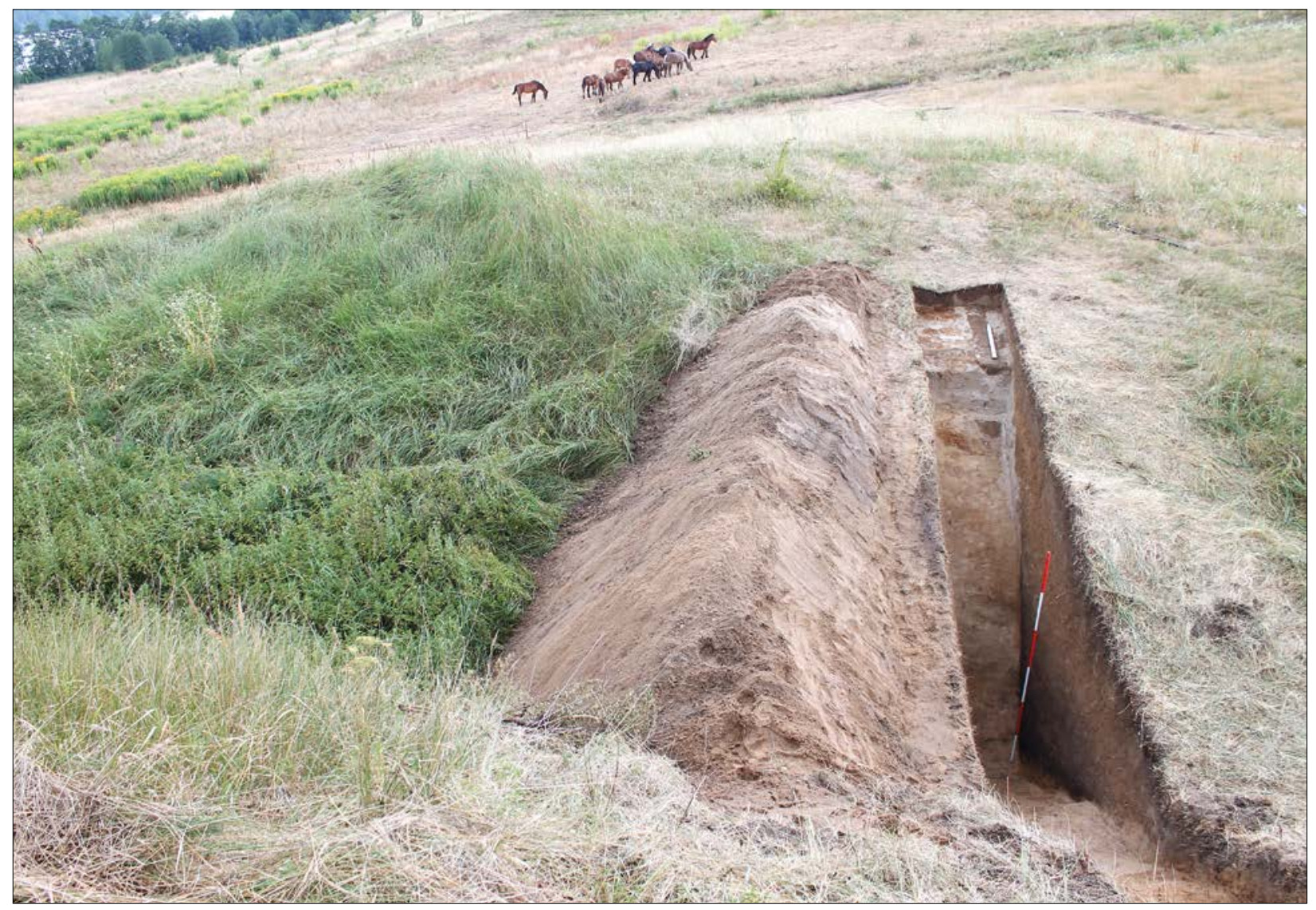

Fig. 4. The deserted town of Alt-Wartenburg (Barczewko). Panorama from the town's west rampart across the moat (with its profile in trench 1/14) to the terrain west of the town, the side of the main attack. Photo by F. Biermann.

perhaps a western tradition. The existence of towers or further fortification elements is uncertain, as the gate's construction is unknown. On the whole, the site was well chosen for natural protection and was strong, but not very elaborately fortified. That this was insufficient became apparent during the 1354 Lithuanian assault.

\section{THE MILITARY CONFLICTS OF THE $14^{\mathrm{TH}}$ CENTURY}

The conquest of Alt-Wartenburg falls in the zenith of the conflicts between the Teutonic Order and its associated dioceses on the one side and the Grand Duchy of Lithuania on the other (Boockmann 1981, pp. 151-169; Paravicini 1989/1995;
Gudavičius 2001, pp. 124-128, 130-131). For both opponents, this was more than just power politics. For the Order, these struggles were its religious raison d'être and its prestige as a defender of Christianity. The 'Lithuanian pilgrimages', popular with the Central European nobility, were of great diplomatic importance in maintaining the Order's ties with the realms of the West as well as attracting young recruits. The Order's main political target was Samogitia, which would enable it to link its possessions in Sambia and Livonia. For the Lithuanians, prestige and religious reasons were also essential. Moreover, the targets of these attacks were not only to weaken the enemy by devastating fields and settlements, but also to strengthen their own economy. Loot and slaves were crucial for the 
economy of the Grand Duchy of Lithuania at that time (Rowell 1994, pp. 74-76).

An example for such raids was the assault by Kęstutis and Algirdas on Alt-Wartenburg in 1354. The brothers, sons of famous Grand Duke Gediminas (d. 1341), had been initially only the Dukes of Trakai and Krèva, but had together become Grand Dukes of Lithuania in 1345/1347, after revolting against their brother Jaunutis (d. after 1366). Algirdas became the Grand Duke and Kęstutis sub-monarch. While Algirdas concentrated on ruling and expansion to the east, Kęstutis dealt mainly with matters in Samogitia and West Lithuania, which made Kęstutis the Order's main opponent (Gudavičius 2001, pp. 131-132). Thus, Alt-Wartenburg was destroyed by an army led by Lithuania's supreme rulers; due to matters of prestige and charisma, the Dukes shared important campaigns and had to lead their warriors into battle. Such campaigns were regularly organised by both sides; war was a permanent condition. For example, the Teutonic Order conducted 96 raids during 13451382, the Grand Duchy of Lithuania 42 such raids during $1345-1377$. All in all, 138 raids by both sides have been documented in less than 40 years (Ivinskis 1978, pp. 255-256). In a wider time frame, between 1305 and 1409, over 300 Teutonic attacks have been documented on Lithuanian territory (Pósán 2014, p. 51).

The Order's chronicles are full of reports of cruel events in the second third of the $14^{\text {th }}$ century; however, because the Lithuanians did not record any chronicles, the written sources enlighten only one side of the conflict. To understand the capture of Alt-Wartenburg, it is instructive to focus on the German-Lithuanian conflicts in Warmia and the neighbouring territory between the 1340s and 1370s, as documented by contemporary German chronicles. The events in the Warmian town in 1354 were only a minor aspect and were a more or less usual incident in these tumultuous times marked by violence and warfare (Fig. 5).
Kęstutis and Algirdas attacked Rastenburg (Kętrzyn) in 1345. On the Order's side, 45 men were killed in front of the town gates and the remaining inhabitants were deported to Lithuania (Voigt 1832, pp. 35-36; Scriptores 1863, p. 508). The two Grand Dukes moved against Rastenburg once more two years later, 1347 (Voigt 1832, pp. 59-60; Scriptores 1863 , p. 508). On their way, they besieged the castle of Gerdauen (Железнодорожный) and burned down four neighbouring villages. Afterwards the Lithuanian forces moved to Leunenburg (Sątoczno), where the Order retained the main castle while the outer bailey and the church were destroyed. After destroying Rastenburg a second time, the Lithuanians moved on Rößel (Reszel), $40 \mathrm{~km}$ northeast of AltWartenburg. In Rößel, the town and castle were devastated. The numerous villages on the way met the same fate. That autumn, a Lithuanian army again attacked the Order's territory, this time in the region of Sambia between Ragnit (Неман) and Insterburg (Черняховск) (Voigt 1832, pp. 59-60; Scriptores 1863, p. 509). As a result of the crushing Lithuanian defeat at the hands of the Teutonic knights and their allies in a battle on the River Strèva on 2 February 1348 (Voigt 1832, pp. 61-65; Scriptores 1863, pp. 510-513), Lithuanian incursions into the Order's lands paused for a certain time.

A new wave of attacks, mostly co-led by the ducal brothers Kęstutis and Algirdas, began in 1352, first with an assault on Sambia (Voigt 1832, p. 93; Scriptores 1863, pp. 518-520), then Rößel in 1353 (Voigt 1832, pp. 103-104; Scriptores 1863, p. 520). After the town and castle of Rößel had been destroyed, the inhabitants were led back to Lithuania as captives. A group of Teutonic Knights followed and attacked them, but the Lithuanians emerged victorious. In order to hasten their return, all of the prisoners, according to chronicle reports, were executed. The following year Alt-Wartenburg was attacked (Scriptores 1863, p. 520), marking the farthest west the Lithuanians had advanced up until 


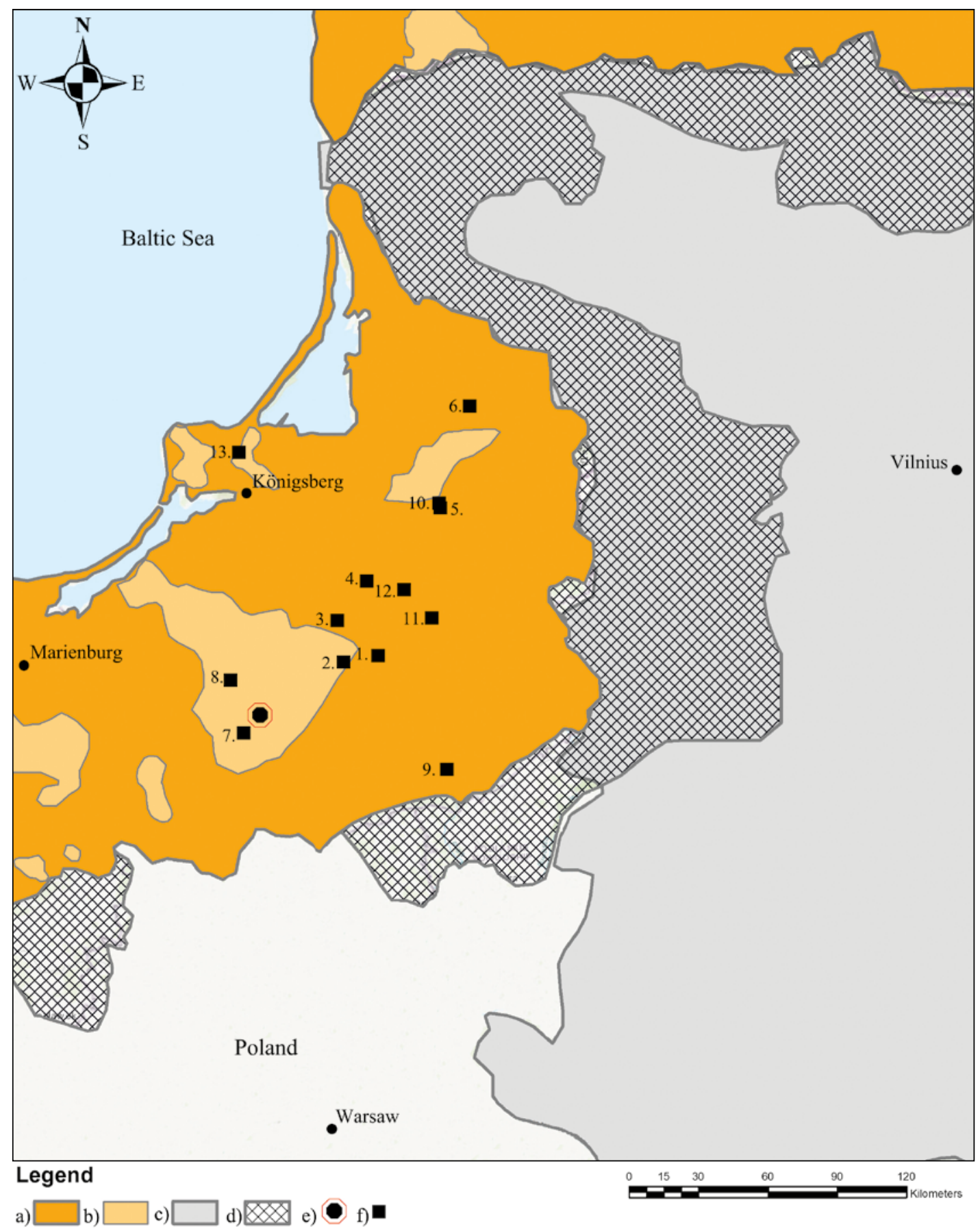

Fig. 5. The $14^{\text {th }}-15^{\text {th }}$ century dominions and the targets of Lithuanian military campaigns mentioned in the text: a) Lands under the rule of the Teutonic Order; b) Episcopal territories in Prussia and Livonia; c) Lands under the rule of the Grand Duchy of Lithuania; d) Lands under the temporary influence of the Teutonic Order; e) Alt-Wartenburg (Barczewko), which was attacked in 1354; f) sites of attacks and battles (with year specified): 1) Rastenburg (Kętrzyn), 1345, 1347; 2) Rößel (Reszel), 1347, 1353; 3) Leunenburg (Sątoczno), 1347; 4) Gerdauen (Железнодорожный), 1347; 5) Insterburg (Черняховск), 1347; 6) Ragnit (Неман), 1347; 7) Allenstein (Olsztyn), 1356; 8) Guttstadt (Dobre Miasto), 1356; 9) Johannisburg (Pisz), 1361; 10) Georgenburg (Маёвка), 1364; 11) Angerburg (Węgorzewo), 1365; 12) Nordenburg (Крылово), 1366; and 13) Rudau (Мельниково), 1370. Plan and drawing by Ch. Herrmann and E. Ubis. 
then. During this attack, the chronicle mentions that apparently no prisoners were taken, the inhabitants being killed immediately. Possibly the Lithuanian leaders concluded from the previous year's experience that taking prisoners so deep in enemy territory and marching them back was too dangerous. As the prisoners had to walk, this slowed the pace considerably and increased the risk of being caught and attacked by the Order's forces.

The next Lithuanian invasion was documented in 1356 when Kęstutis and Algirdas struck Allenstein about $10 \mathrm{~km}$ southwest of Alt-Wartenburg (Voigt 1832, pp. 119-120; Scriptores 1863, p. 522), but the town and the castle were able to repulse the siege. So the Lithuanians devastated the area between Allenstein and Guttstadt (Dobre Miasto), destroying 17 villages. The intensity of the Lithuanian attacks decreased in the following years. Kęstutis destroyed Johannisburg (Pisz) in 1361 (Scriptores 1863, pp. 530531), but was then captured by the Order and imprisoned at Marienburg (Malbork) Castle, from which he soon escaped. In 1364 he invaded the area of Georgenburg (Маёвка) in Sambia; the following year he devastated the areas around Angerburg (Węgorzewo) and Scalovia (Skalva) (Scriptores 1863, pp. 548-550). In 1366 the Lithuanians attacked Nordenburg (Крылово) and Johannisburg (Scriptores 1863, pp. 554-555, 557-558). Kęstutis and Algirdas prepared a great invasion of the Teutonic Order's territory in the winter of 1370 and with the assistance of Russian and Tatar forces, assaulted North Sambia. On 17 February 1370, a large battle took place at the small town of Rudau (Мельниково) north of Königsberg (Калинингра́д). The Lithuanians and their allies suffered a severe defeat at the hands of the Teutonic Order's forces led by Grandmaster Winrich von Kniprode (d. 1382) and the Grand marshal of the Order, Henning Schindekopf, who died on the battlefield (Voigt 1832, pp. 212-219; Scriptores 1863, pp. 565-567). This by no means ended Lithuanian incursions into the Order's territory; attacks occurred almost every year of this decade, just as the Order's military expeditions into Samogitia continued.

The Lithuanian incursions into the Order's territory were usually conducted in winter (as were most of the Order's campaigns in Lithuania) because it was easier to ride on the frozen paths and wetlands; Chronicler Heinrich von Lettland (d. after 1259) notes that already in the early $13^{\text {th }}$ century the Lithuanians used sleighs to move in their operational area and to carry away the booty from their raids on Christian territories in Livonia (Heinrich von Lettland 1959, XI. 5). Wigand von Marburg reports exact dates for some of the Lithuanian attacks on towns and castles, such as the destruction of Rastenburg on 22 February 1347 (Scriptores 1863, p. 508), the invasion of Sambia in February 1352 (Voigt 1832, p. 93), the attack on Rößel in 1353 (Scriptores 1863, p. 520), and the raid in the area of Allenstein in January 1356 (Scriptores 1863, p. 522). On 14 February 1370, a large Lithuanian army invaded Prussia followed three days later by the decisive battle at Rudau. It can, therefore, be assumed that Alt-Wartenburg was also attacked in the winter, probably in early spring 1354.

\section{LITHUANIAN WARFARE IN THE $14^{\mathrm{TH}}$ CENTURY}

It is unknown whether there were Teutonic Order troops or regular Episcopal forces in Alt-Wartenburg on the day of the attack. If the nearby castle still existed, such units were probably billeted there, but Wigand says nothing about it and, as discussed above, no archaeological evidence points to their existence. The presence of a powerful Lithuanian army, in contrast, is mentioned explicitly by the chronicler. The Lithuanian forces were rooted in martial retinues that undoubtedly existed in the Roman period $\left(1^{\text {st }}-5^{\text {th }}\right.$ centuries) at the latest, but had probably arisen even earlier (Michelbertas, Vitkūnas 2003; Merkevičius 2005). However, the transformation of tribal warrior companions into an effective army: the 
steps in the process and the extent of any side effects and changes, are still hotly debated (Dediala 2018). Effective, well-organised armed forces already existed indisputably in the $10^{\text {th }}-12^{\text {th }}$ centuries. Their genesis was influenced by social and environmental changes in the tribal Baltic communities. According to the scarce written sources, the Grand Duke's armed forces were created during the development of the kingdom of Mindaugas (d. 1263) and the internal conflicts between various dukes in the second half of the $13^{\text {th }}$ century (Nikžentaitis 1992, p. 5). The army's basis was a general military obligation in the Grand Duchy of Lithuania: every man had to defend the land in the event of an enemy invasion. Such defensive forces assembled only temporarily, of course (Batūra 1964, pp. 84-85; Gudavičius 1992, pp. 43-44). The obligation for the noblemen and their retinues, i.e. the 'bayores, etc.' mentioned by Wigand von Marburg in his short description of AltWartenburg, to participate in offensive raids declined. These raids, like in Alt-Wartenburg in 1354, were mostly organised under the direct command of the Grand Dukes or their close relatives.

The tactics and combat methods of the Lithuanian raids can only be determined ambiguously. From written sources, it is known that the infantry was the basis of the armed forces of the Baltic tribes until the $13^{\text {th }}$ century (Nikžentaitis 1992, p. 7), cavalry being of minor importance. There is, however, a written record of horsemen armed with spears and maces on a battlefield already in the early $13^{\text {th }}$ century. Chronicler Heinrich von Lettland described the fast horses the Lithuanians used in raids in Livonia and the tactics of the Lithuanian cavalry (Heinrich von Lettland 1959, XI. 5 [1207], XII. 2 [1208]; Vitkūnas 2011). On the other hand, cavalry was of major importance to the Teutonic Order (Nowakowski 1994, p. 105).

Archaeological discoveries have been of limited significance in understanding Lithuanian warfare because most of them cannot be dated precisely.
However, the spear was apparently the dominant Baltic weapon during the $9^{\text {th }}-13^{\text {th }}$ centuries (Kazakevičius 1998, p. 39). In addition, swords, arrowheads, and battle axes are frequent finds. The crossbow was an innovation derived from western practices and used by Lithuanian warriors at the latest from the second half of the $13^{\text {th }}$ century (Vaičenonis 2011, p. 24).

However, the Lithuanian military experienced major changes in the $14^{\text {th }}$ century due to the rising confrontation with the Teutonic Order, the concentration of power in the Grand Duchy, the expansion into Russian lands and the confrontation with the Golden horde khanate, and general economic and social developments. The crossbow became the dominant distance weapon in the Grand Duchy of Lithuania starting in the $14^{\text {th }}$ century. An analysis of various types of bolt heads showed that the majority of the Lithuanian bolts had tanged heads, with a gradually increasing percentage of socketed heads (Rackevičius 2002, pp. 62-67). The artefacts associated with bows, crossbows, and arbalests showed that, in many respects, the Lithuanian army used armaments similar to those of the German knights and other Central European forces. This dovetails especially well with the weapon finds from the northwest part of the Grand Duchy, the scene of many warlike and peaceful contacts, there being not just martial, but also diverse cultural interactions between the communities of the Grand Duchy of Lithuania and the Teutonic Order (Urbonaite-Ubè 2018; Ubis 2018). Chivalric values and the art of jousting emerged among Lithuania's elite at that time (Pósán 2014, pp. 52-58), but the Teutonic knights also adopted weapons common in the Grand Duchy of Lithuania and further east (Vaičenonis 2011, p. 39). In the course of the endless wars between them, both sides assimilated to each other. Thus, at the 1410 Battle of Tannenberg (Grunwald/Žalgiris), for example, it was nearly impossible to distinguish the best-equipped Lithuanian units from their German opponents (Nikžentaitis 1992, p. 31). 
Moreover, in the second half of the $14^{\text {th }}$ century, the use of armour and its variety increased among Lithuanian warriors. The most popular being scale and plate armour, chain mail, and brigandines (Bugys 2014). The complex armour indicates new influences on Lithuanian armour from the east and west. These changes were linked to transformations in Lithuanian tactics and combat methods. While the use of crossbows is mostly interpreted as a change in the defensive aspects, the rise of armour is explained by the increasing importance of cavalry in the grand duke's army; cavalry may have had special importance in raids such as the one at Alt-Wartenburg because of its quickness and agility. The spear was still the predominant Lithuanian weapon, as archaeological grave finds from the $14^{\text {th }}-15^{\text {th }}$ centuries indicate (Kuncevičius 2005, pp. 128-129; Petrauskas 2017, pp. 123-124). The complexity of the armament also grew. In the mid- $14^{\text {th }}$ century, Lithuanian armed forces consisted of light cavalry, crossbowmen, infantry, and siege machines such as catapults. On the whole, Lithuania's armed forces became more and more like the continental European armies in the course of the $14^{\text {th }}$ century, with one exception: the Eastern European expansion of Lithuania's Grand Dukes led to strong eastern influences in cavalry weapons and armour, as is shown by the archaeological data. Not only were elements of the weaponry of the equestrian nomads adapted (Bugys 2014), but some Lithuanian warriors apparently also dressed in an Eastern Slavic style (Nowakowski 1994, p. 111). Others, however, were hardly distinguishable from their German or Western European opponents (Batūra 1964, p. 93).

The attack on Alt-Wartenburg was one of many raids surely executed with the usual combat methods and tactics. The attacking forces were composed of various military units. Fast, mobile cavalry was the most important component during such raids while crossbowmen and infantry played a lesser role, but such units probably used horses to reach the target and dismounted before the battle.

\section{TRACES OF THE SAVAGERY AND VIOLENCE AT THE ALT-WARTENBURG SITE}

Herald Wigand von Marburg gives no details about the event in 1354 . He only describes the conquest of Alt-Wartenburg by the ducal brothers, the nobles, and their retinues and the fact that none of the inhabitants escaped. What that meant is shown by the archaeological findings, which present a picture of devastation: completely destroyed houses with all their burned furniture preserved in a 'Pompeii effect', the bodies of the dead in the rubble of the burned cellars, the numerous bolt and arrowheads witnessing to the wild free-for-all in the town's streets, and the silver coins hidden by panicked inhabitants behind cellar walls.

Apparently, the inhabitants of Alt-Wartenburg were taken by surprise and quickly enveloped because no one escaped, as Wigand states. When there was advance warning, the townsfolk unable to fight would have probably fled and hid in the then still dense forests; this was a usual practice, as is shown, for instance, by the reports of Heinrich von Lettland roughly 150 years before (Heinrich von Lettland 1959, XI. 5, XII. 2). The assumption of a successful Lithuanian surprise attack is also suggested by the archaeological findings, because no precautions had been taken to hide valuable equipment: iron-tipped ploughs and other farming equipment, iron skewers, a bronze kettle, etc (Figs. 6, 7), which were still in the cellars where they had been deposited before the unexpected disaster. Likewise, things suitable as weapons, such as heavy axes, remained inaccessible in the cellars on that day. Artefacts pointing to a siege: earthworks, breaches in the rampart, and stone catapult balls or similar items used by siege machines, have also yet to be found, which may also corroborate the assumption of a lightning-fast Lithuanian conquest. Another indication of a surprise coup could be that the 2013-2019 detector surveys showed the majority 


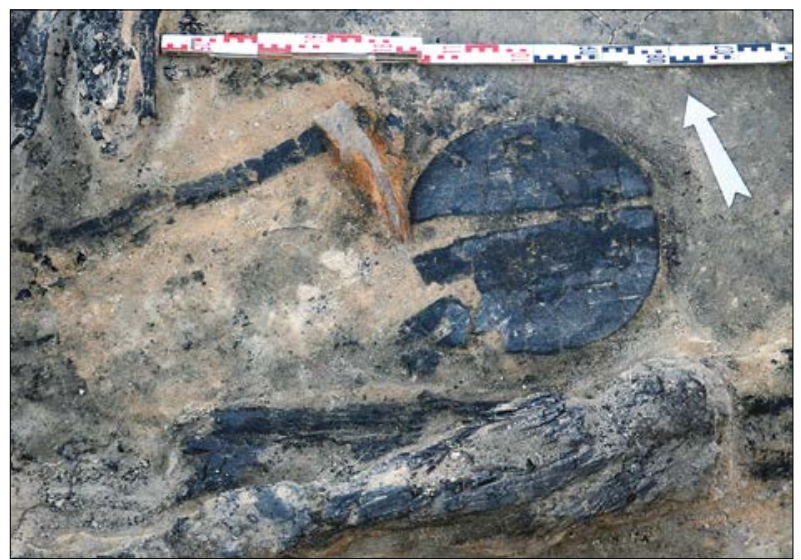

Fig. 6. The deserted town of Alt-Wartenburg (Barczewko). An iron pick with a burnt wooden handle and a barrel lid in a cellar, obj. 158. Photo by A. Koperkiewicz. of the bolt and arrowheads to be inside the town, rather than outside it or the fortifications, but this is ambiguous because of several reasons discussed below. The town's rapid capture is also confirmed by finds of food and food remnants in several houses, which indicates that the supplies had not yet been used up. The bathhouse, for instance, yielded about two dozen jugs and pitchers, which had been sunken into the tavern's ground floor above the cellar's ceiling (Figs. 8, 9) and contained a large quantity of chicken eggs as witnessed by thousands of small shell fragments. Another cellar contained large quantities of grain, which had been spread by the firestorm, yet another, still standing barrels that might have contained beer (Fig. 6), and yet others, the remnants of wickerwork baskets (Fig. 10) that perhaps held fruit.

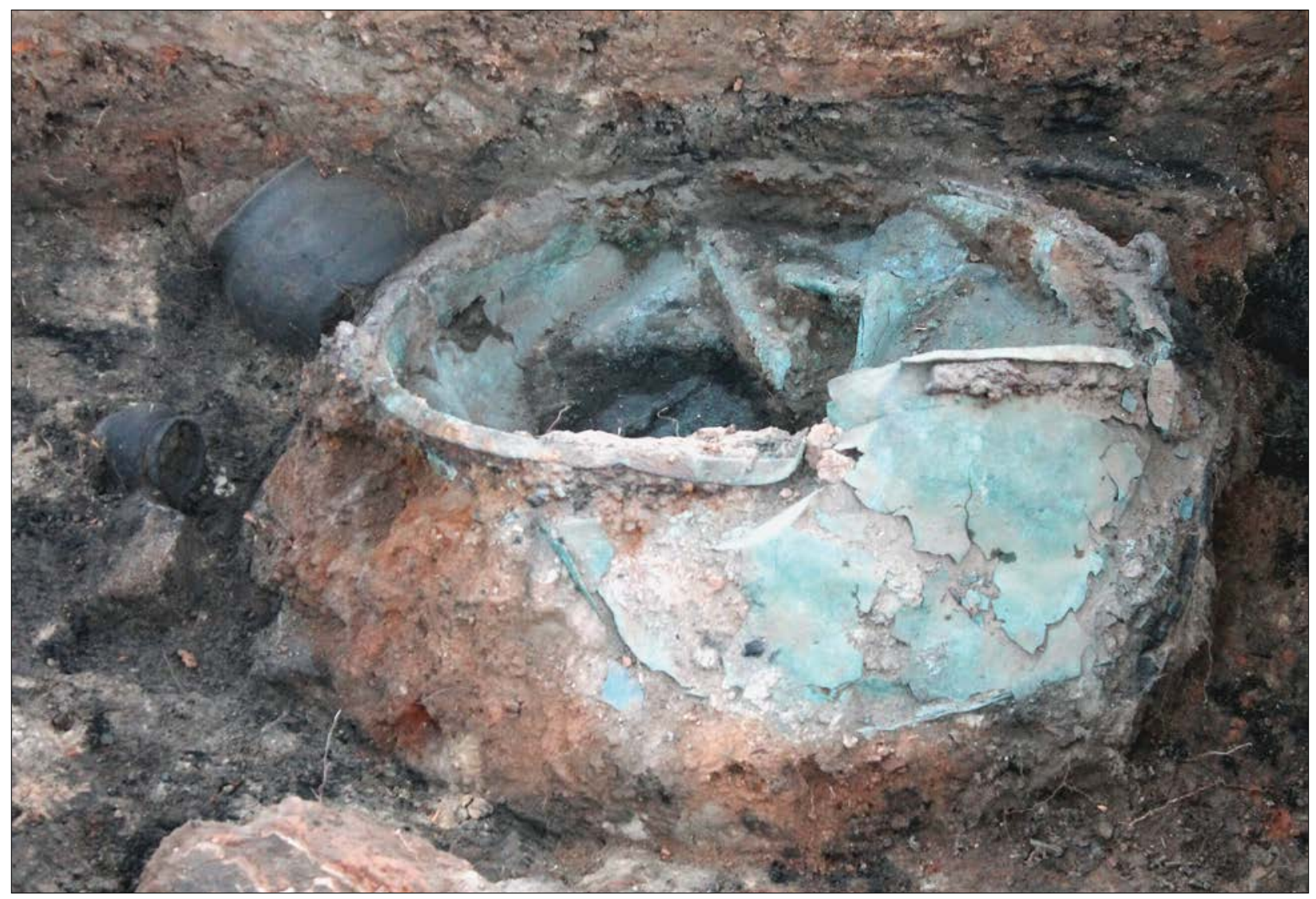

Fig. 7. The deserted town of Alt-Wartenburg (Barczewko). A bronze cauldron with an iron handle and ceramic vessels in an outhouse, obj. 234. Photo by F. Biermann. 


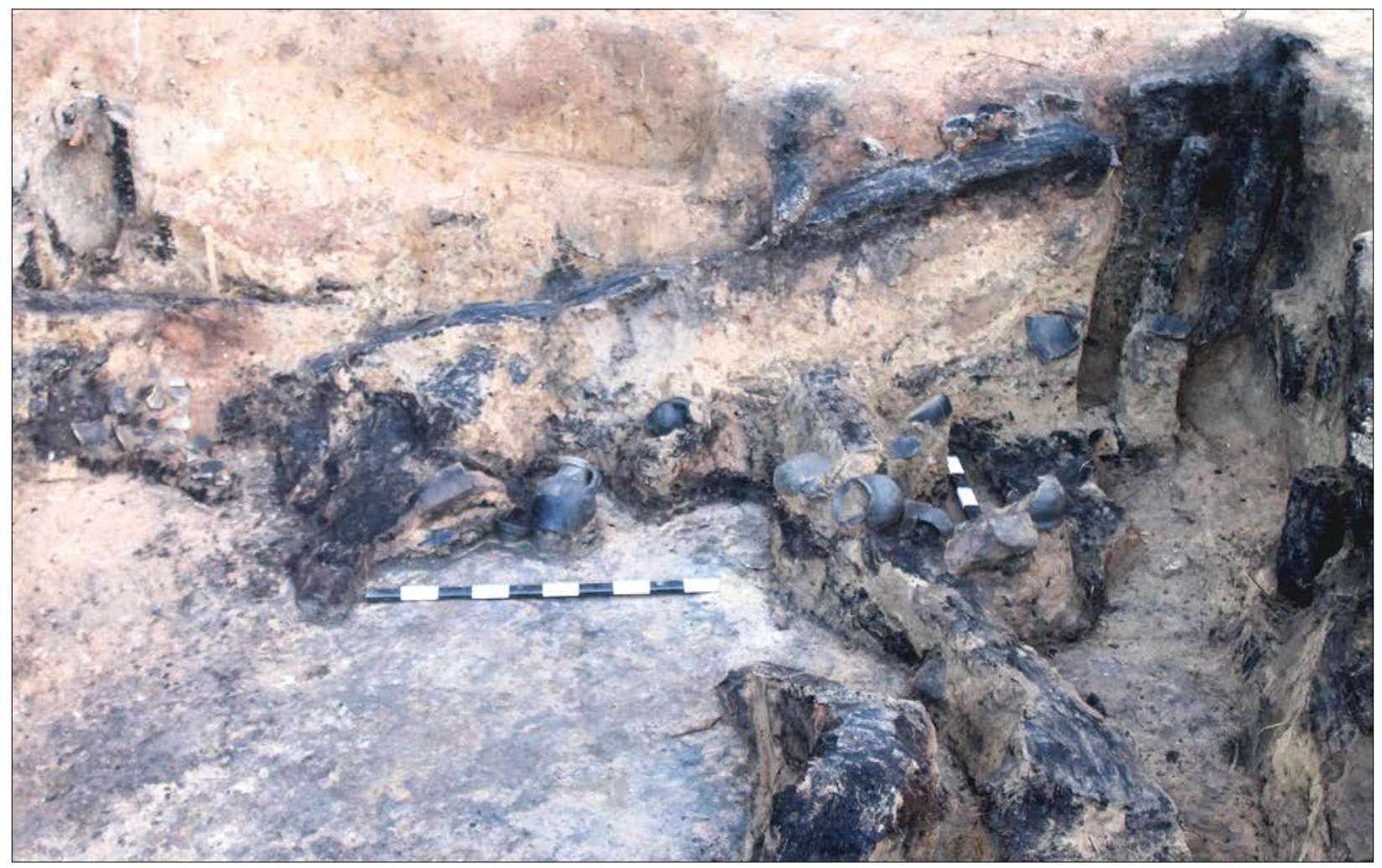

Fig. 8. The deserted town of Alt-Wartenburg (Barczewko). The cellar of the bathhouse, obj. 224, with a collapsed timber and sunken clay vessels cellar. Photo by F. Biermann.
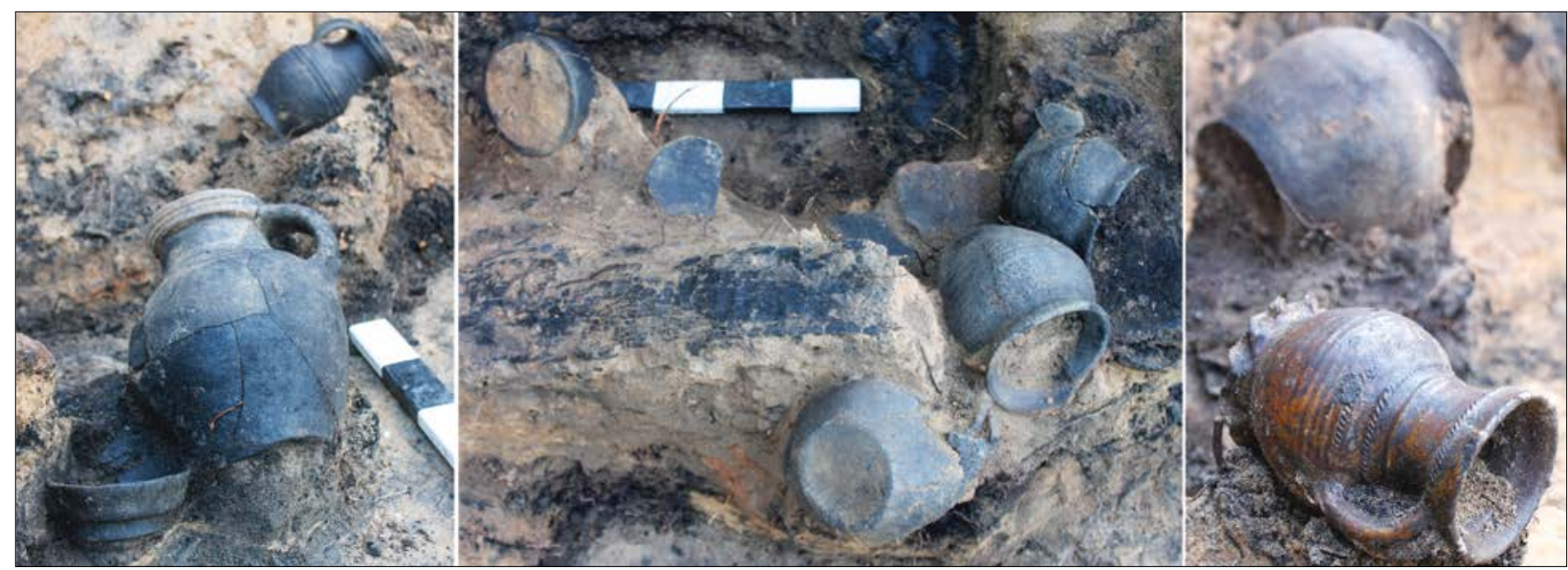

Fig. 9. The deserted town of Alt-Wartenburg (Barczewko). Ceramics in the fire debris of a cellar, obj. 224, including an imported, glazed semi-stoneware jug. Photos by F. Biermann.

How the attackers overcame the town's fortifications is not yet clear. The distribution of bolt and arrowheads in the systematic detector surveys do not show any definite concentrations indicating fighting hot spots at specific fortification locations; in the strict sense, as emphasized above, there were no projectiles at all at the town's main ramparts (Fig. 11). But this result is probably not significant: the entire 


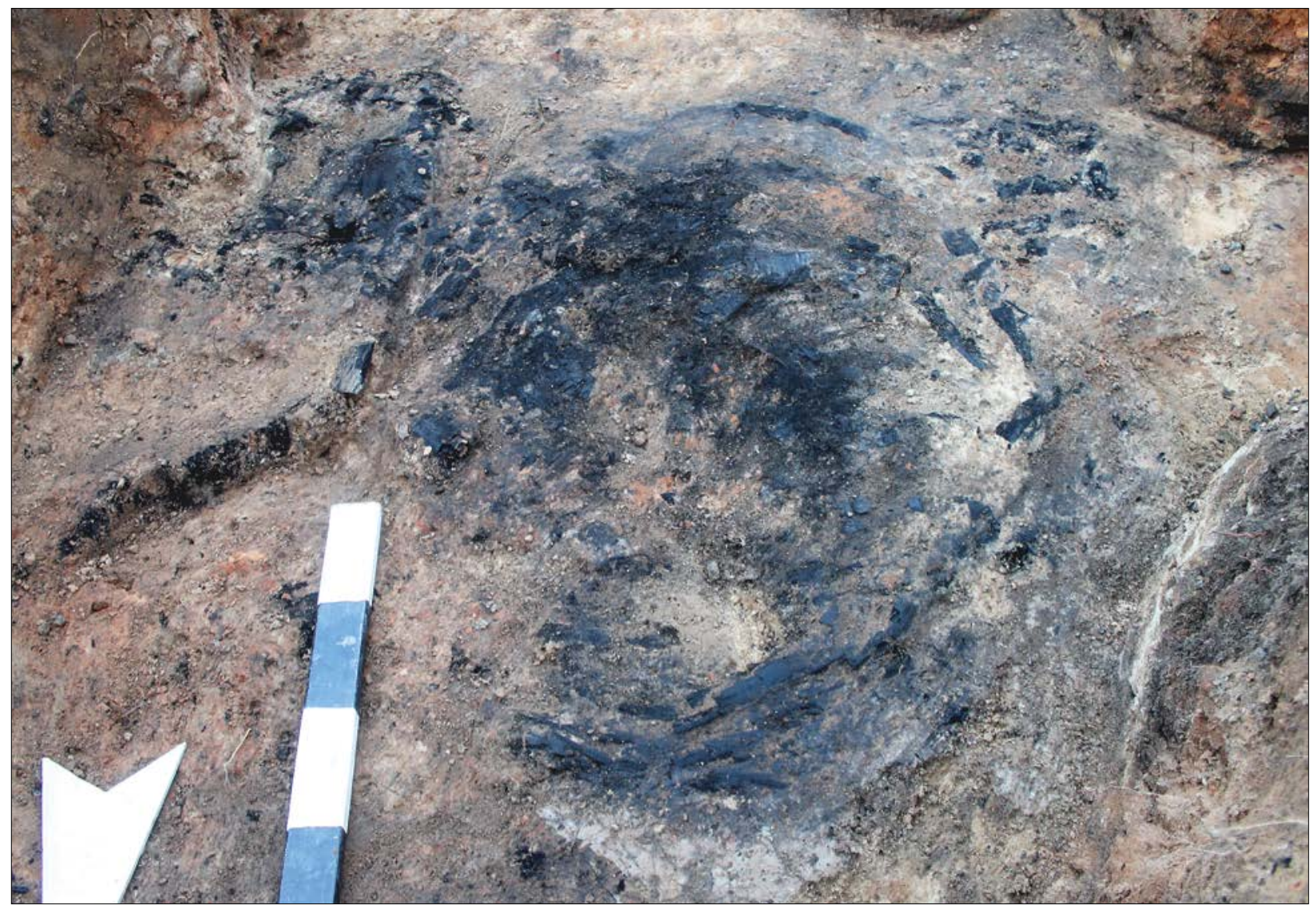

Fig. 10. The deserted town of Alt-Wartenburg (Barczewko). Wickerwork from a basket in a cellar, obj. 566. Photo by F. Biermann.

area had sparse metal finds in the beginning of the research. Metal objects were preserved virtually only in the cellars and deeper cultural layers. The rather poor results of the detector survey could have had several reasons, of course. A plausible explanation, however, is the assumption that the widely known, but remote site was already the target of intensive illegal metal detector activities, which distorted the historical distribution. Therefore, it is nearly impossible to draw conclusions from the metal find distribution pattern.

The number of crossbow bolts was indeed conspicuous on the southeast slope of the town hill and the adjacent area of the town. The sparse concentration of projectiles might indicate that fights had occurred there. Possibly a smaller group of attackers entered the town from the rear, unseen by the defenders, concealed by the main force attacking the west rampart. In any case, the attackers entered the town and heavy fighting occurred there; since the fire debris of most of the ten excavated houses contained bolt and arrowheads, it can be assumed that street fighting occurred inside the town. The distribution of these weapons suggests that the centre of these violent events was, unsurprisingly, the market place with the mercatorium on its south side. The inhabitants, scared to death with good reason, probably fled to the central point of their community and defended themselves there for a while. Since far more bolt heads have been found inside the town than outside it, this corroborates the idea of a successful coup de main.

As has already been emphasized, however, the incidence of the projectiles cannot deliver more than an adumbration of the events of 1354 due to 


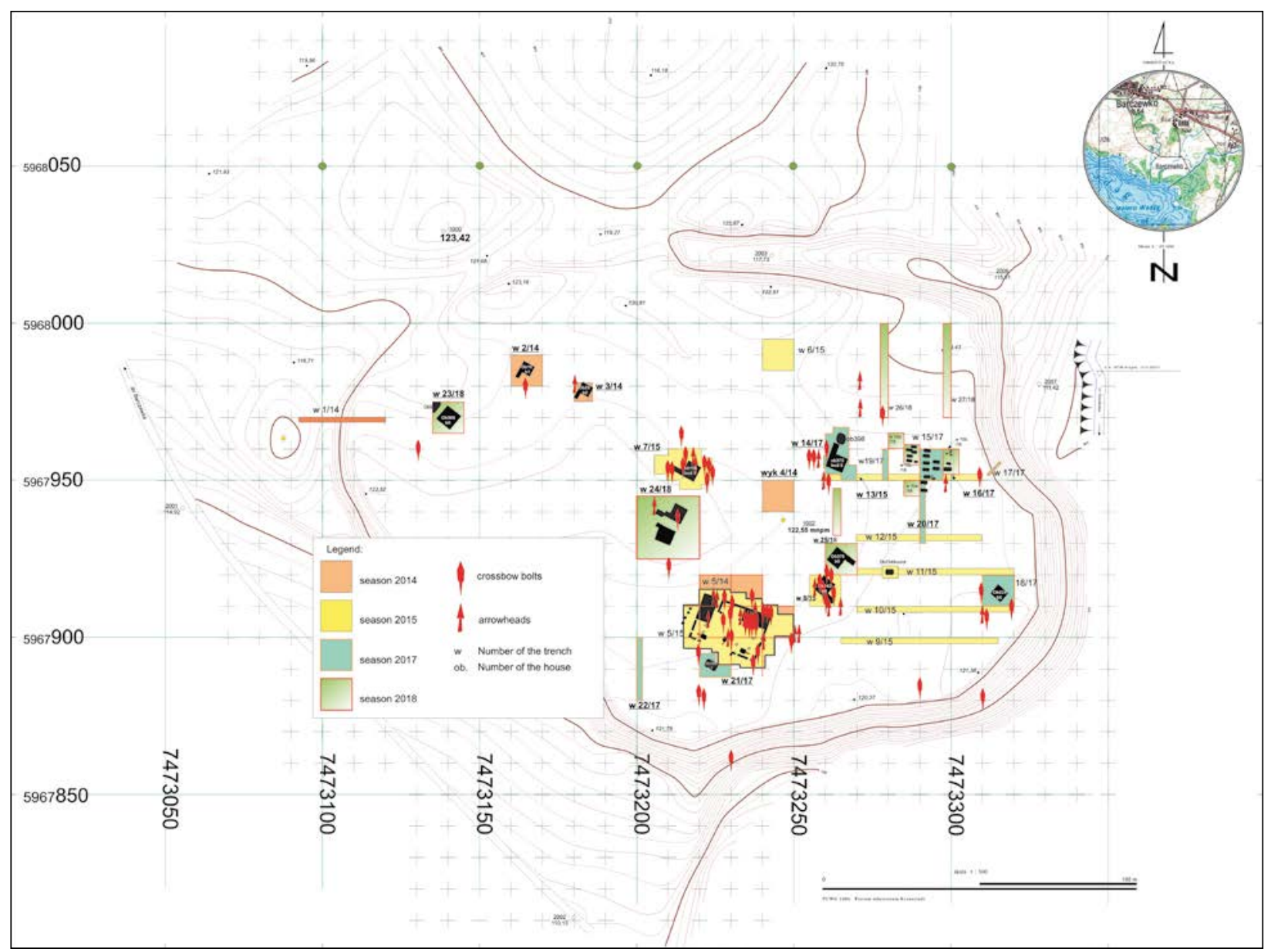

Fig. 11. The deserted town of Alt-Wartenburg (Barczewko). Plan of the site and the trenches showing the most important features and the distribution of the bolt and arrowheads. Created by A. Koperkiewicz and A. Napierała.

methodological limitations. But the archaeological and historical records coincide in the main fact, that the residents of Alt-Wartenburg, just a small group of people including women, children, and the elderly, probably had little chance against the battle-hardened Lithuanian warriors. As has already been stressed, the chronicler remains silent on any possible help by the Teutonic knights or episcopal troops and the archaeological evidence points to nothing else.

Among the weapons spread throughout the town, bolt and arrowheads predominate (Fig. 12). Approximately 80 projectiles were discovered until
2018 (Napierała 2019)3 , mostly in the fire debris of house cellars and in the town hall complex. The bolt heads are mainly heavily thickened, square, and tapered; it is easy to imagine the terrible effect these projectiles had on a human body. The arrowheads are a little daintier. Most of the projectiles have tangs that were driven into the wooden shafts. Compared to a socket, this variant was faster to produce and the iron heads broke off reliably from the wood shaft upon impact with a hard target. Thus the arrows or bolts could not be shot back by the enemy. Sockets are rare and found mainly on arrowheads, which

\footnotetext{
${ }^{3}$ More have been found in the excavation campaign 2019, beneath else a kind of deposit of 155 crossbow bolts.
} 


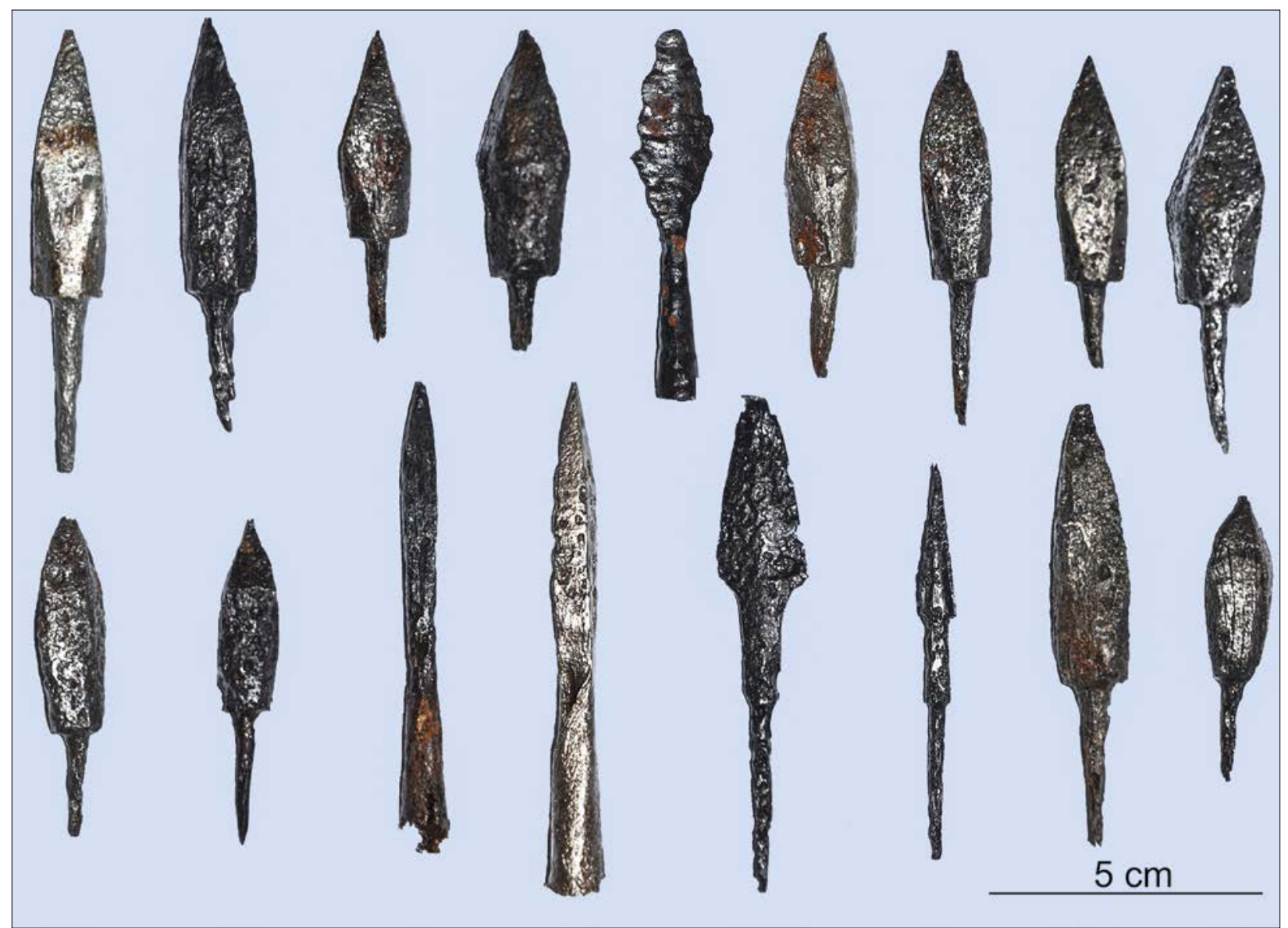

Fig. 12. The deserted town of Alt-Wartenburg (Barczewko). Iron bolt and arrowheads. Photo by A. Koperkiewicz.

are represented less at the Alt-Wartenburg site than bolt heads: about two-thirds of the heads can be attributed to crossbows, a third to bows, which corroborates the decreasing importance of the bow among Lithuanian and German fighters in favour of the crossbow. The effective, pinpoint accurate crossbow with its enormous penetration power had already prevailed for military purposes.

This applied to both, Lithuanians and Germans; in every age military opponents assimilate to their opponents' armaments. It is, therefore, nearly impossible to attribute the individual bolt or arrowhead by type to the attackers or defenders. In the case of Alt-Wartenburg, of course, there is considerable reason to believe that most of the projectiles were shot by the men of Kęstutis and
Algirdas and on the whole the specimens are very comparable to Lithuanian finds. Moreover, several relatively light iron arrowheads with a tanged tetragonal head or rhomboid blade correspond very well to known Lithuanian military equipment, the latter type having been adapted from the Lithuanians by equestrian Nomads (cf. Медведев 1966; Świętosławski 2011; Napierała 2019, p. 48).

Some of the projectiles, indeed, may have also belonged to the stock kept for hunting purposes at Alt-Wartenburg. However, the majority of the iron projectiles attest to the brutality of the town's demise in 1354, several bearing traces of the conflict. An iron catch for spanning a crossbow was discovered near the inner face of the town's west fortification and was therefore perhaps used by the defenders. 


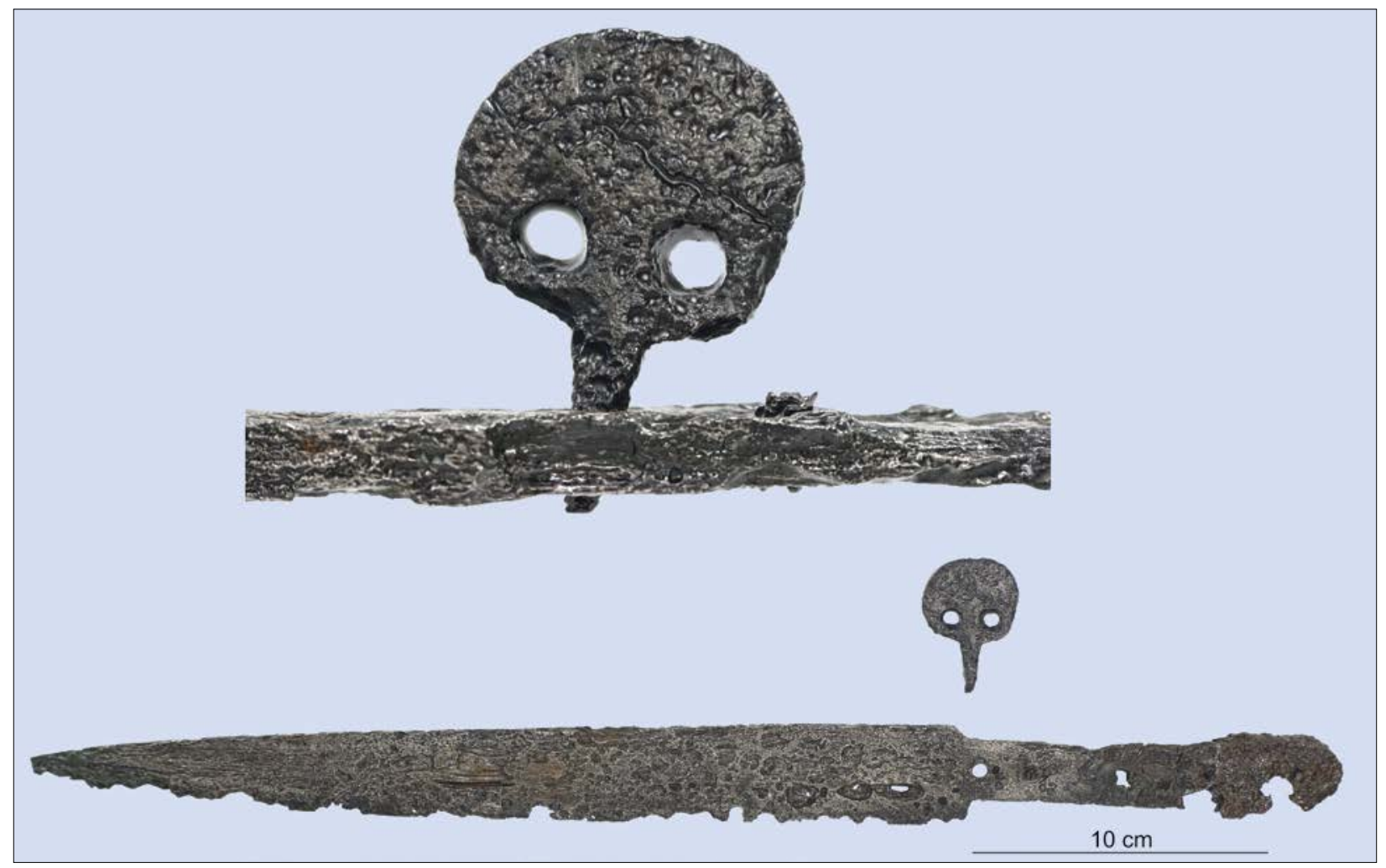

Fig. 13. The deserted town of Alt-Wartenburg (Barczewko). The iron Bauernwehr, a full view and a detail. Photo by J. Strobin.

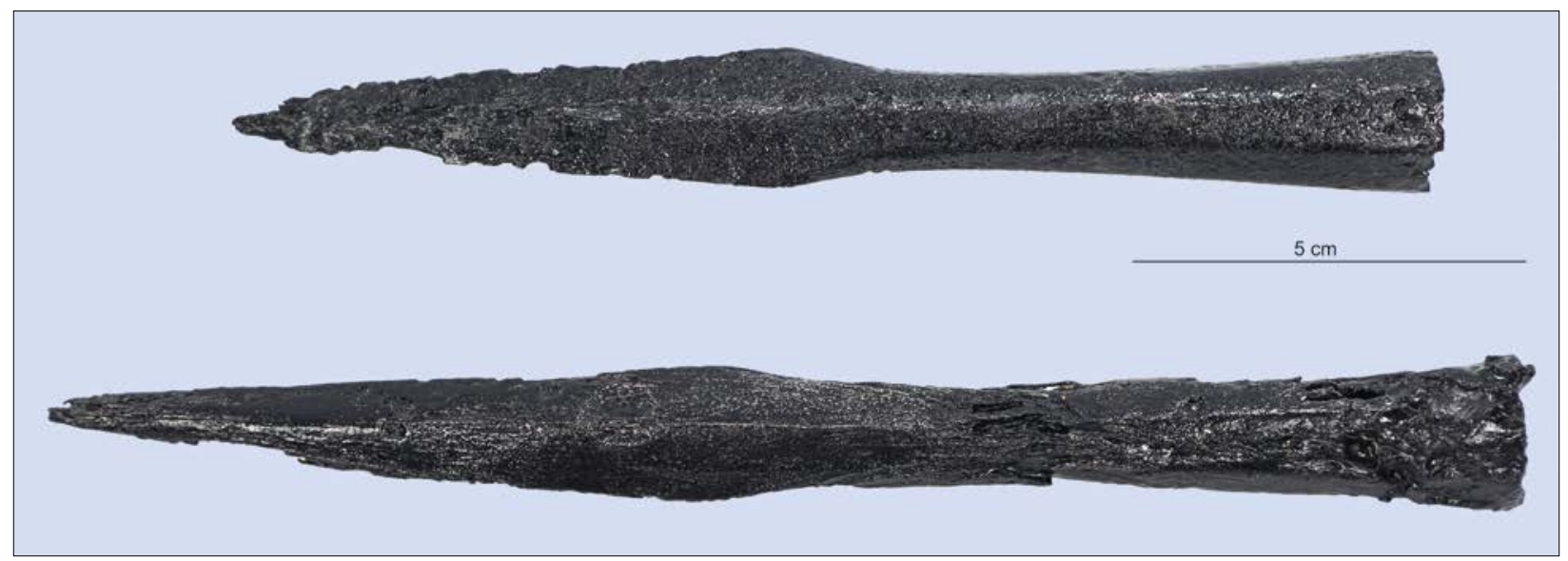

Fig. 14. The deserted town of Alt-Wartenburg (Barczewko). Two iron spearheads. Photo by M. Pacholec.

A long knife, a so-called Bauernwehr ('farmer's protection') (Fig. 13), may well have belonged to an Alt-Wartenburg inhabitant; such a weapon was often worn as a multipurpose tool, but also as a social emblem. It has a simple hand protection in the form of a separate, elongated rivet with a round head, which was rose from the hilt where it met the blade. It was found in the vicinity of the mercatorium. It is, therefore, uncertain as to whether it had been used at the last fight by its owner or not. Two small spearheads belonged to light throwing weapons (Fig. 14); spears were, as mentioned above, still one 


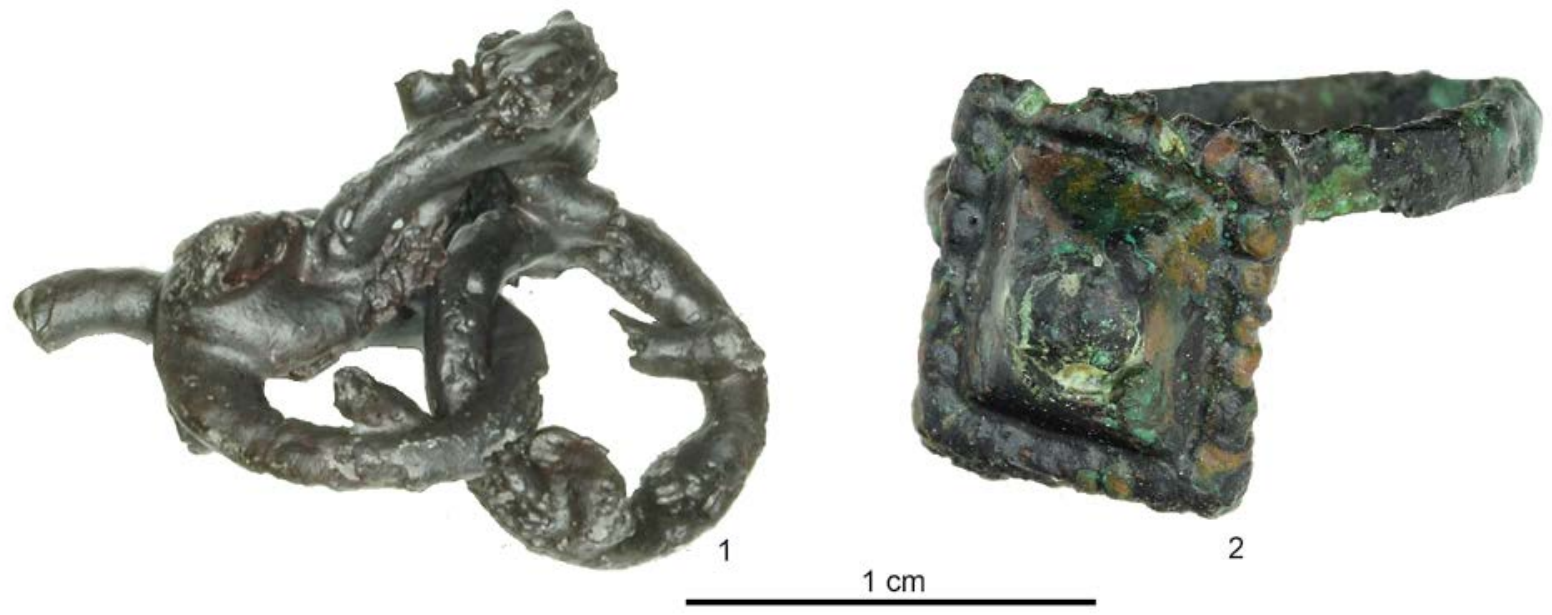

Fig. 15. The deserted town of Alt-Wartenburg (Barczewko). Iron rings from chain mail (1) and the bronze ring from the young woman in a cellar, obj. 576 (2). Photo by J. Strobin and A. Koperkiewicz.

of the main weapons of the Lithuanians in the $14^{\text {th }}$ century. Several riding spurs and spur fragments were, just like a ring-shaped part of a bridle, used by well-equipped cavaliers, i.e. Teutonic knights, representatives of the Bishop, and wealthy citizens. In addition, a small piece of iron chain mail was discovered (Fig. 15.1). These finds, of course, are not necessarily connected with the last day of Alt-Wartenburg.

The clearest evidence of the terrible destructive rage that hit the town in 1354 is the burnt houses. The town was virtually wiped out by fire: all of the previously excavated building structures had become victims of fire as shown by the completely carbonized wooden cellar structures and the burnt clay of the collapsed walls and ceilings (Figs. 16-19). In the absence of stone and brick buildings, the town was easily destroyed by fire. The arson apparently occurred during the conquest, not later, i.e. after the extensive plundering of the houses and as the completion of the destructive event. One Lithuanian war aim was usually looting and marauding, as emphasized above, but in Alt-Wartenburg this aim was obviously not foremost. Numerous useful tools as well as other objects and valuables had survived under the fire debris: the ceramic pots were still in the places where they had been on the morning of that fateful day. The kettle with its paraphernalia had been waiting for over 660 years; axes, scythes, a plough, and a pick were still leaning against the walls. Apparently, the fire started right at the onset and then no one bothered to look for anything valuable in the rubble. The ability to search for booty after the attack would have been questionable because the enormous heat that arose during the burning of the half-timbered houses severely damaged everything. For instance, many pottery vessels had softened and become deformed.

While a fire could have unintentionally started during the fighting, the young town was not yet densely developed and thus, a burning house would not have automatically resulted in a conflagration that would destroy the whole town. This suggests that the Lithuanian warriors systematically set fire to each house in turn. Alt-Wartenburg must have lit up the sky like a torch over wintry frozen Lake Wadąg. Perhaps the invaders were nervous because of their raid so deep in enemy territory. The foreseeable difficulty in returning was perhaps the reason they refrained from looting and displacing people like they 


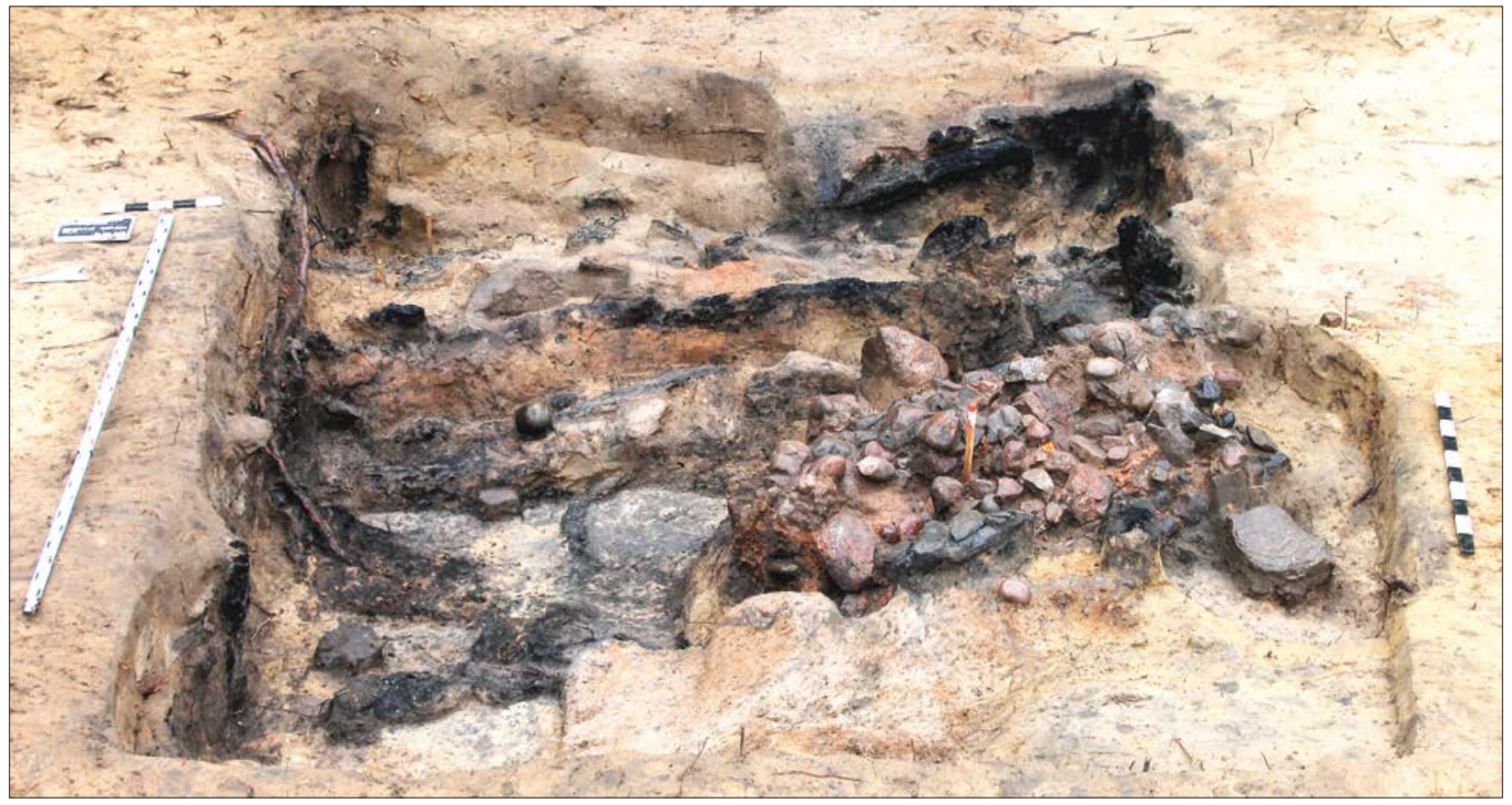

Fig. 16. The deserted town of Alt-Wartenburg (Barczewko). The cellar, obj. 224, of the burnt bathhouse with a collapsed stone oven and large quantities of timber and clay behind the stairs. Photo by F. Biermann.

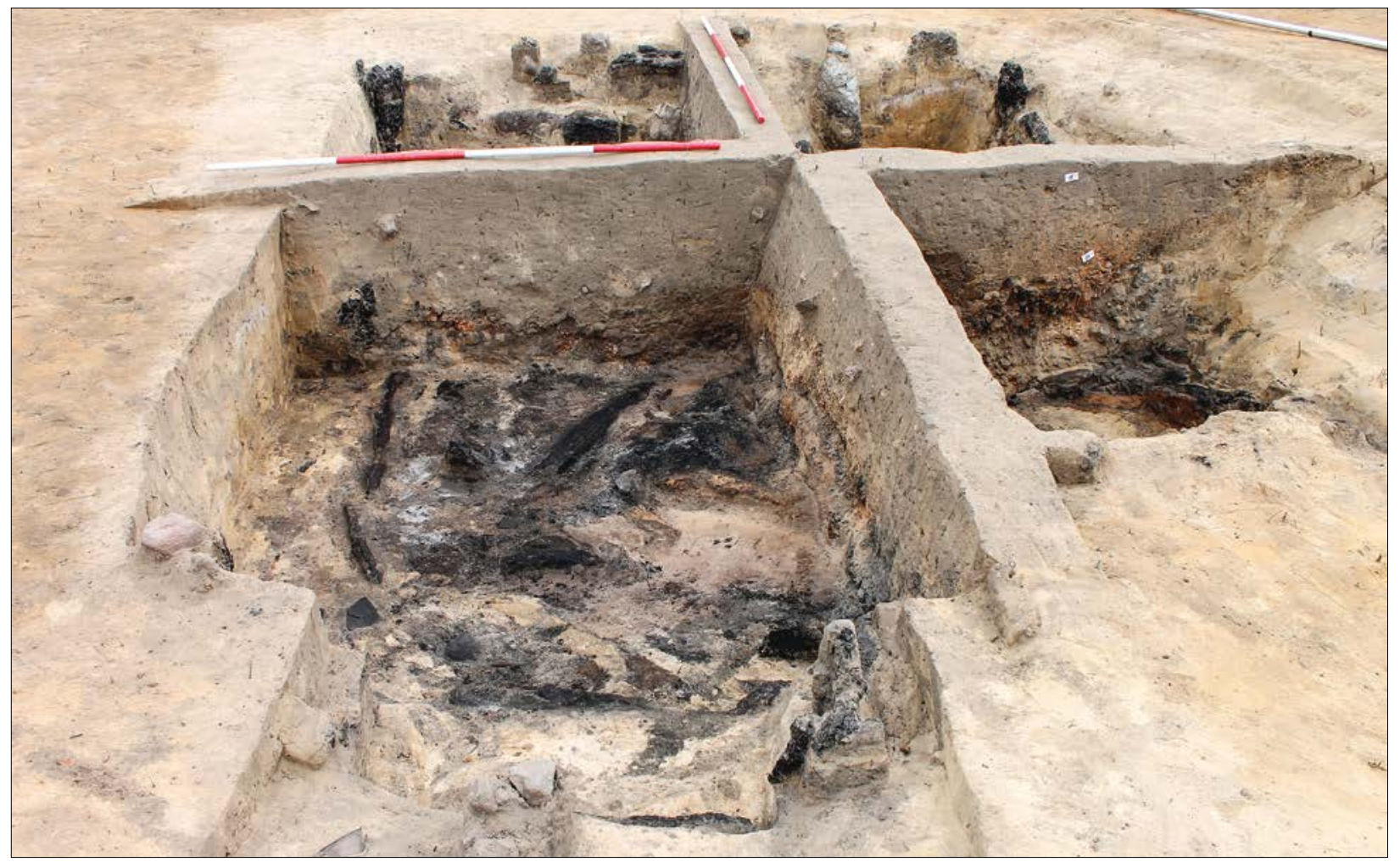

Fig. 17. The deserted town of Alt-Wartenburg (Barczewko). A cellar, obj. 16, filled with masses of fire debris, as seen through the entrance. Photo by F. Biermann. 


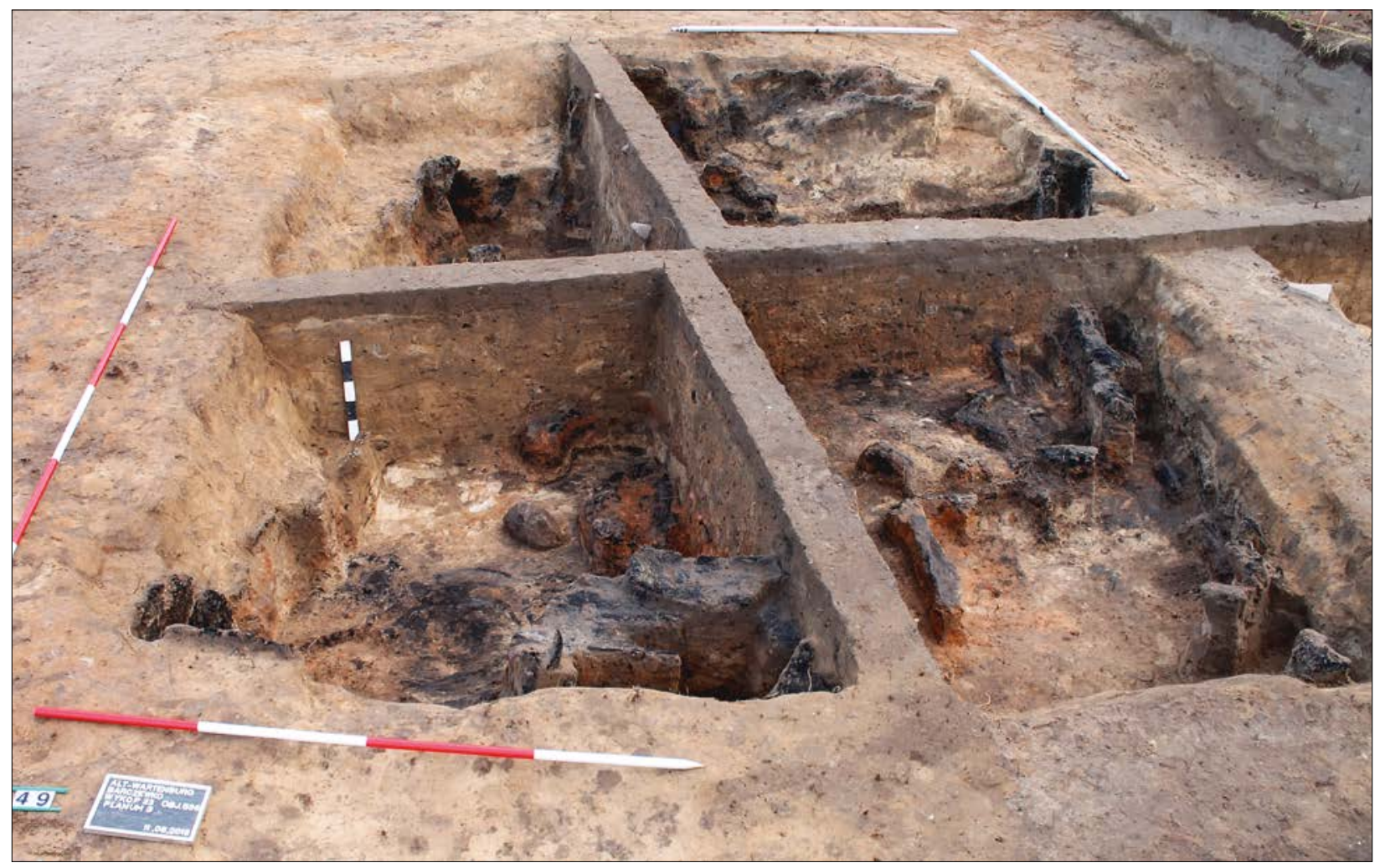

Fig. 18. The deserted town of Alt-Wartenburg (Barczewko). A burnt cellar, obj. 566, with timber and clay from the walls and ceiling. Photo by F. Biermann.

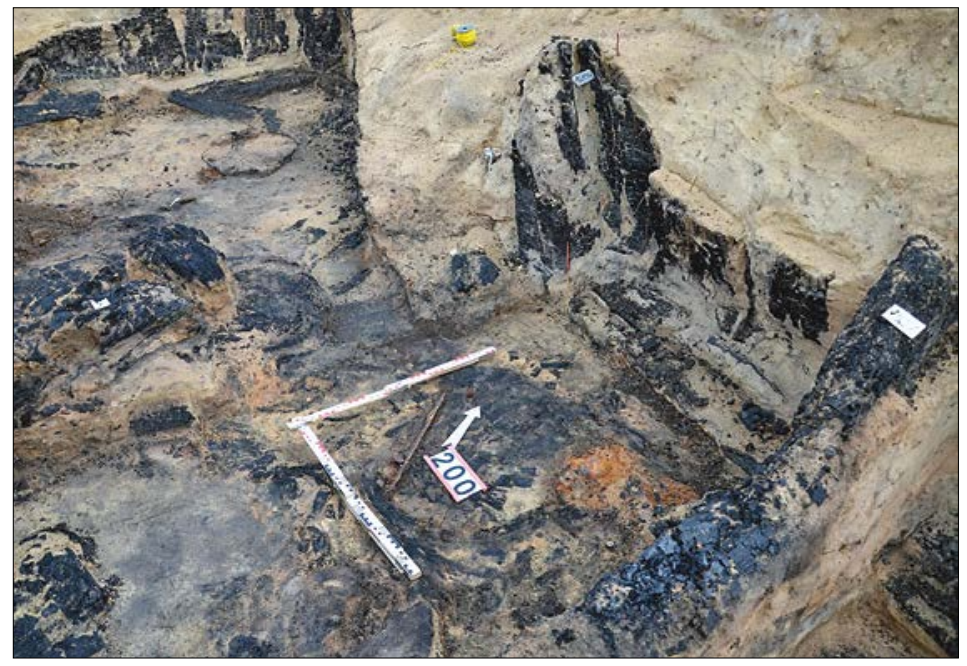

Fig. 19. The deserted town of Alt-Wartenburg (Barczewko). A completely burnt cellar, obj. 158, with fire debris and the remnants of various containers and tools. Photo by A. Koperkiewicz. usual did. It is also possible that Kęstutis and Algirdas were in extraordinary hurry because of approaching German knights and so they eschewed looting, took no prisoners, burned everything down, and departed quickly.

The fear and fate of the inhabitants of Alt Wartenburg is evident in two groups of finds. On the one hand, small concentrations of silver coins (usually Teutonic Order and Warmian Bishopric bracteates), obviously small change and wealth, which had been lost or hidden when the owners were in mortal danger, were found on numerous occasions, beneath else hidden behind the timber of wall structures in various cellars (including those of the mercatorium). 


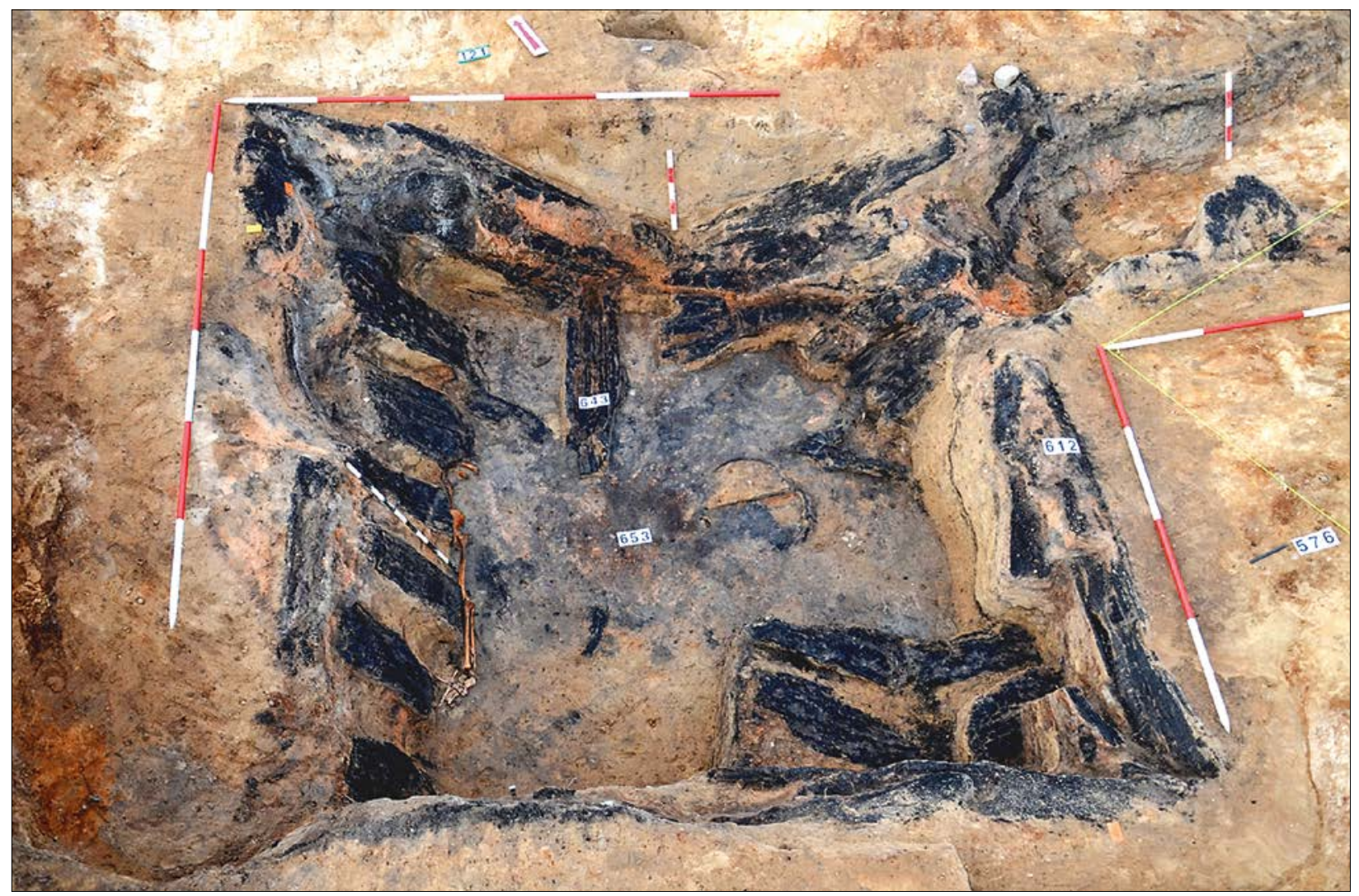

Fig. 20. The deserted town of Alt-Wartenburg (Barczewko). A cellar, obj. 576, with a collapsed wooden structure; on the left the skeleton of the young woman is visible. Photo by A. Koperkiewicz.

About 20 such concentrations, numbering from a few coins to up to 17 , were recovered; in all, the Alt-Wartenburg project has resulted in 157 silver coins until 2018.

On the other hand, two cellars contained the human remains of inhabitants who tried to hide in the hour of their greatest need: hopeless attempts to pluck themselves from the jaws of death. In a cellar at the market place, a young woman of 18-20 years was found under the collapsed timber walls with her face to ground and her skull shattered, probably by falling beams (Figs. 2022). Her arms were folded in front of her

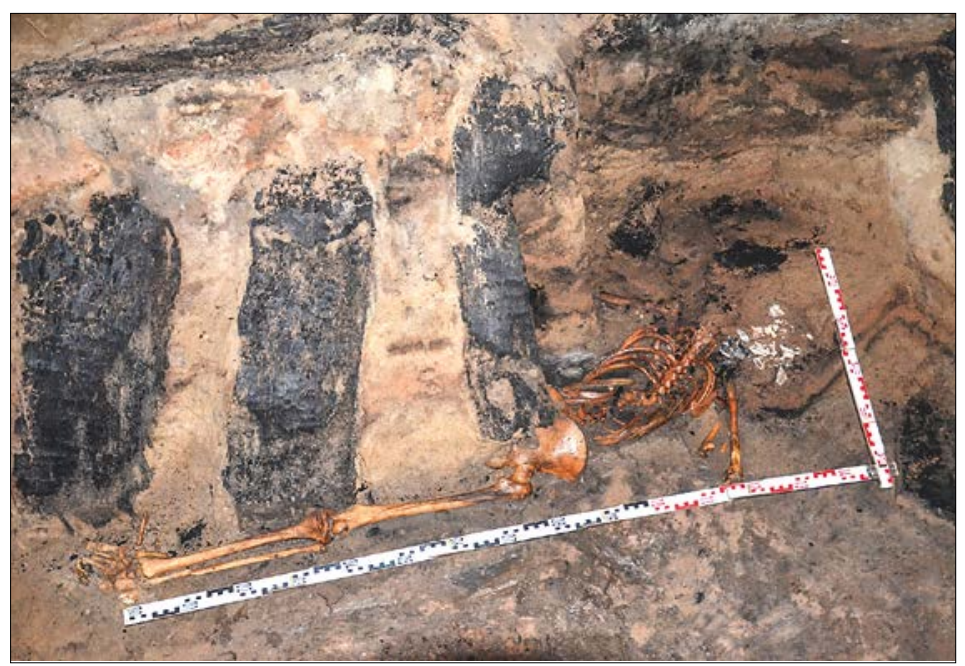

Fig. 21. The deserted town of Alt-Wartenburg (Barczewko). The skeleton under a collapsed timber in the same cellar. Photo by A. Koperkiewicz. 


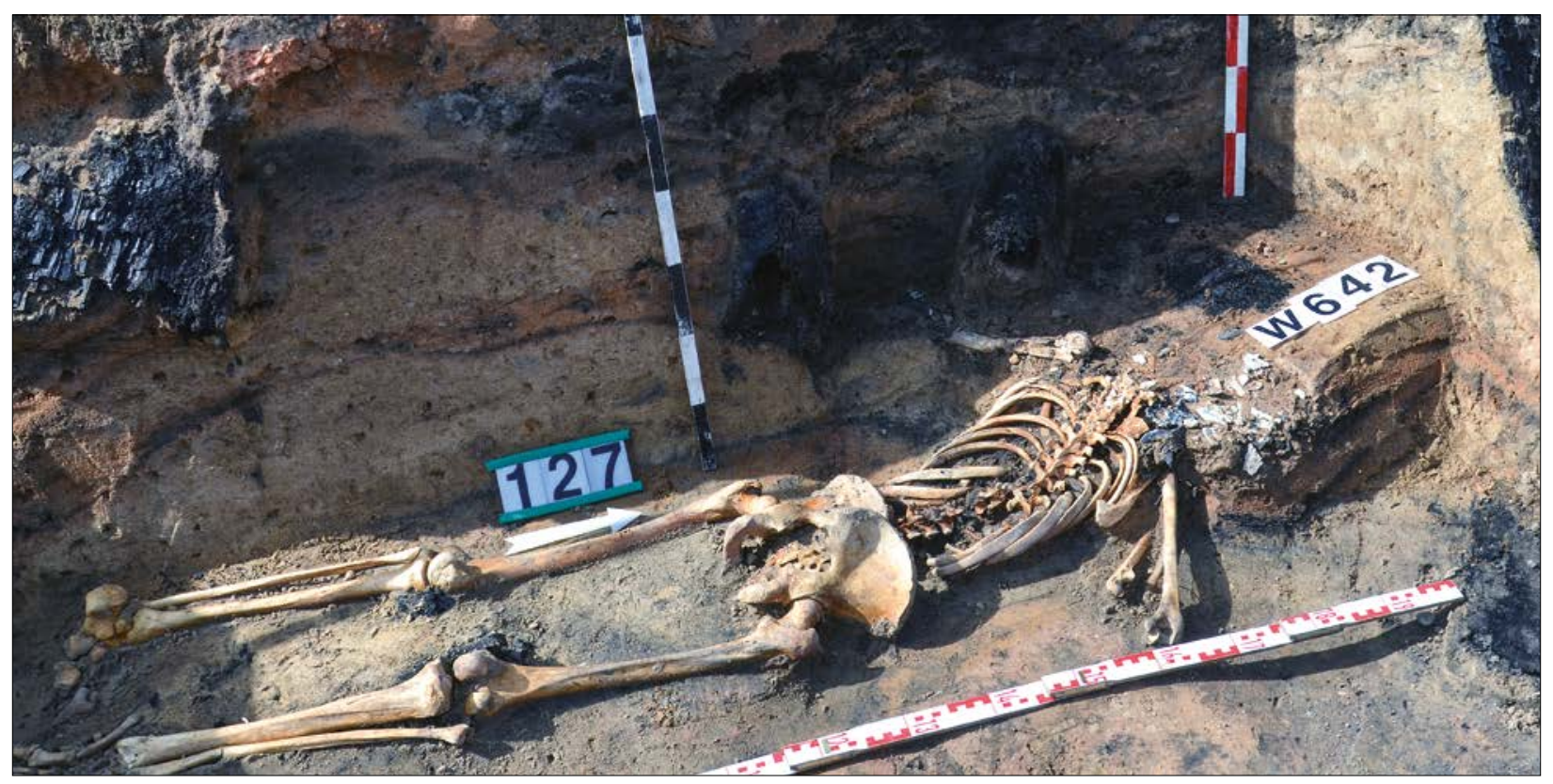

Fig. 22. The deserted town of Alt-Wartenburg (Barczewko). A complete view on the skeleton. Photo by A. Koperkiewicz.

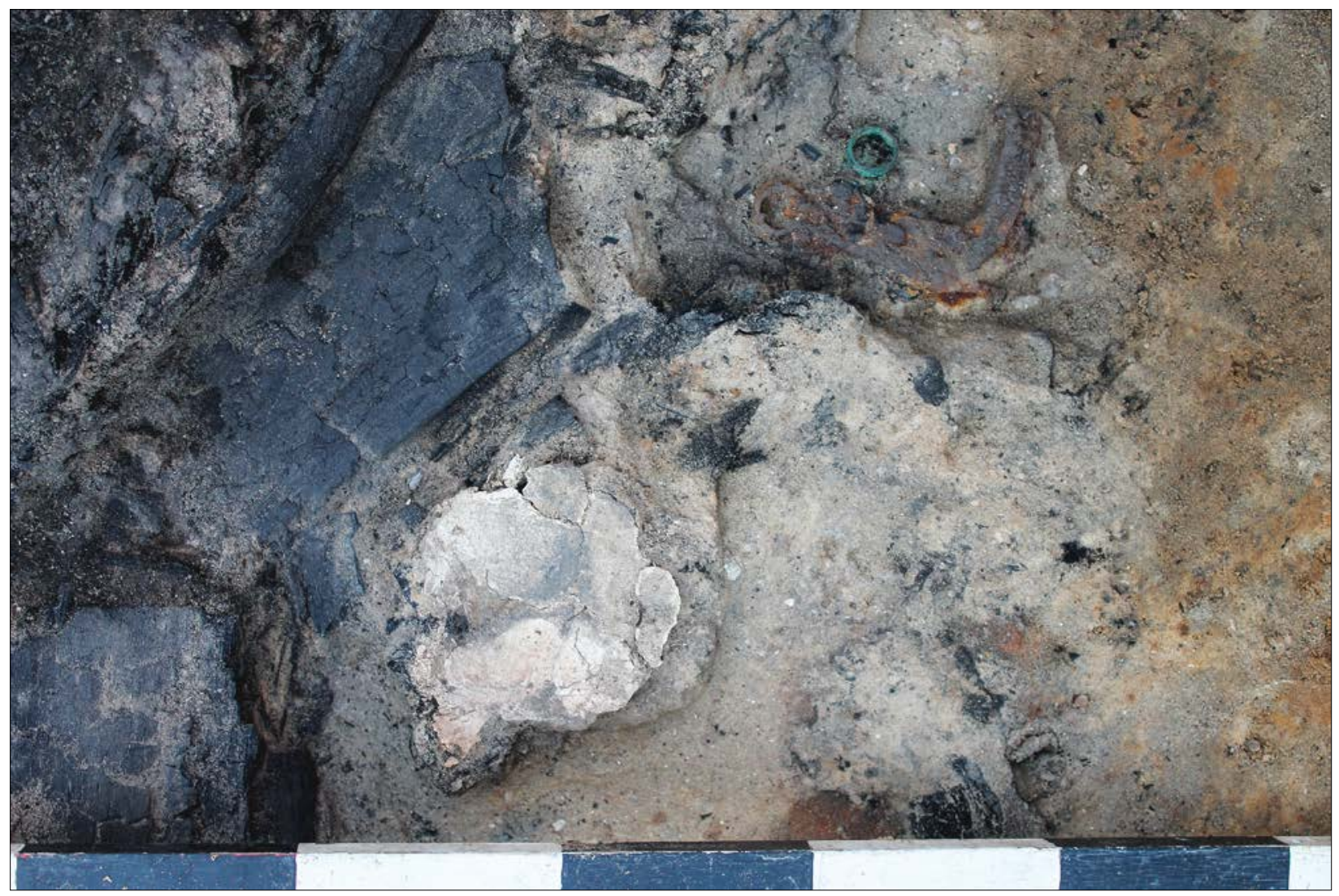

Fig. 23. The deserted town of Alt-Wartenburg (Barczewko). The skull of a child under fire debris in a cellar, obj. 162, together with ornaments and iron tools. Photo by F. Biermann. 
chest and she had a bronze ring on her right hand (Fig. 15.2). That this ornament had not been taken by a looter could indicate that the woman had not been robbed and killed directly, but had hidden herself in the cellar and died of the flames, smoke, and collapsing parts of the burning house. On the floor of another fire-damaged market place cellar lay the bones of a year-old child, buried under fire debris (Fig. 23). ${ }^{4}$ Nearby were two silver rings, which had certainly not been worn by this toddler. Therefore, it is possible to speculate whether they had been left there, together with the child, by the desperate mother, who had escaped, been captured, or been killed elsewhere.

The skeletons were found only at the bottom of debris-filled cellars, where they had been missed during the salvage and clean-up work following the massacre. The great mass of bodies had likely been recovered and buried at the order of the Episcopal reeve, probably in the yard of the destroyed church. However, the current excavations in the cemetery have yet to produce a mass-grave, but they have covered only a small part of the cemetery. It is also possible that the bodies had been taken to the yard of another, intact church in the vicinity of the henceforth lost town of Alt-Wartenburg.

\section{CONCLUDING REMARKS}

The archaeological results presented here assign Alt-Wartenburg to a group of early historical and medieval era sites in the wider region, which reveal evidence of war and violence. Excavations at castles have repeatedly yielded large numbers of bolt and arrowheads as well as human remains, for example: Kaukai hillfort (Alytus District in Lithuania) where the skeletal remains of 25-30 individuals were found alongside numerous arrowheads in the courtyard, probably the victims of an $11^{\text {th }}$-century attack by
Kiev Rus' warriors (Vitkūnas, Zabiela 2017, p. 57), Maišiagala hillfort (Vilnius District in Lithuania) where burnt buildings, burnt food supplies, and other artefacts associated with attacks by the Order from 1365 and 1390 were discovered (Kulikauskienè $1972 ; 1974)$, the $14^{\text {th }}$ century castles, which were built by the Order on the River Neman and were where large quantities of crossbow bolts, remnants of the constant fighting for these military bases, were found (Tautavičius 2001), and the motte castle at Plement (Plemięta) near Graudenz (Grudziądz), which was destroyed at the latest during the Hunger War of 1414 by Lithuanian and Polish troops, but potentially already some decades earlier since. Large quantities of burned timber, several iron chain mail remnants, helmets, weapons such as swords and axes, numerous bolt heads, and nine burnt human bones were found there (Nadolski 1985). Hence, Alt-Wartenburg is in general no exception. Remarkable archaeological evidence actually exists from many sites, attesting that the masses of weapons found in the graves from that period were used for their real purpose, that the many strong hillforts and castles in this region were not only symbols of power but also sorely needed in a warlike era, and that the comprehensive written record about martial events reflects the real circumstances of that time.

However, the finds from Alt-Wartenburg provide exceedingly impressive insights into a dramatic event in a violent epoch: the numerous weapons and burned buildings at the site as well as the isolated forgotten victims of violence present a scene of total destruction. The excavations have enabled archaeologists to retrace the conquest and destruction of the town in 1354, have produced extensive insights into the course and details of these cruel events and allow the incidents to be imagined (Figs. 24, 25). In particular, the site indicates that the brutal details of the Order's chronicles were, at

\footnotetext{
${ }^{4}$ Anthropological determination: Alicja Drozd-Lipińska.
} 


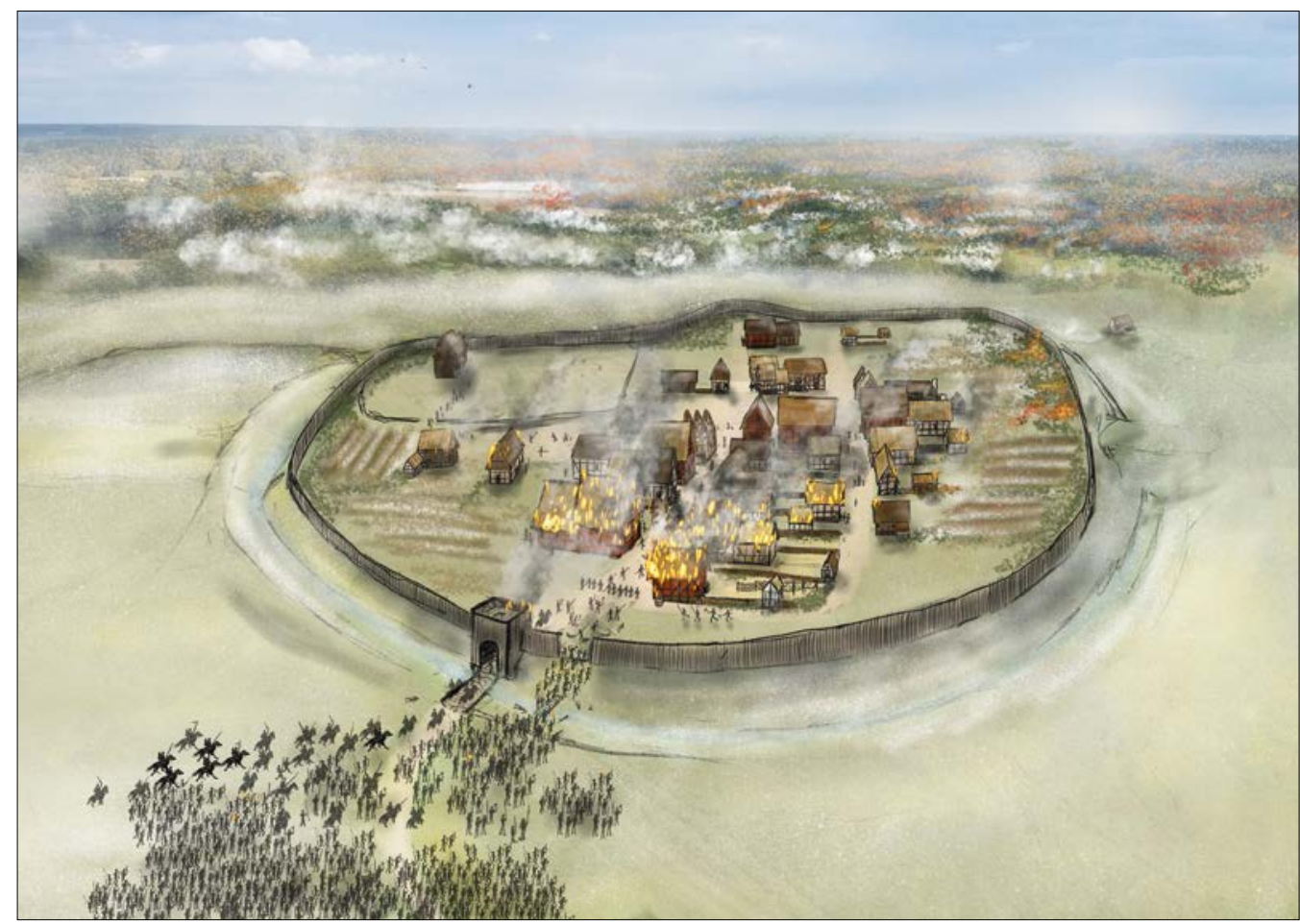

Fig. 24. The deserted town of Alt-Wartenburg (Barczewko). The town during the Lithuanian attack in 1354 as seen from the west, an artist's impression. Drawing by L. Plith Lauritsen.

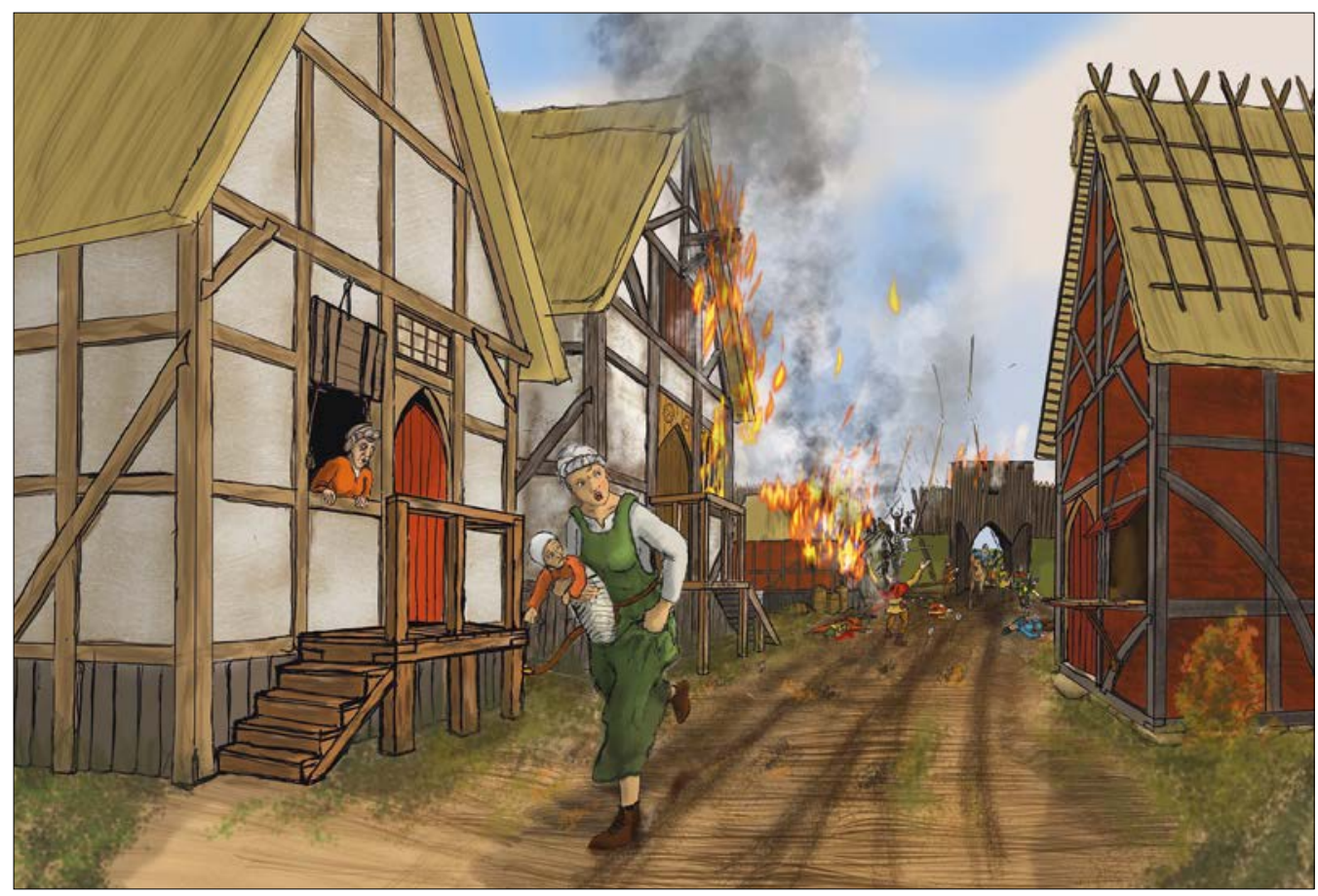

Fig. 25. The deserted town of Alt-Wartenburg (Barczewko). The main street during the Lithuanian attack in 1354 as seen from the west, an artist's impression. Drawing by L. Plith Lauritsen. 
least in principle, no exaggerations to slander the opponent, not only given the completely burned down town and the traces of suddenly interrupted everyday life, but also given the numerous bolt and arrowheads as well as the finds of human remains in the cellars. On the whole, the research verifies and supplements the historical record concerning the fall of Alt-Wartenburg and its circumstances as evidence for a warlike era.

\section{REFERENCES}

Batūra, R., 1964. Karinè organizacija Lietuvoje XIII-XV a. In: Jurginis, J., red. Lietuviu karas su kryžiuočiais. Vilnius: Mintis, 84-109.

Biermann, F., Herrmann, Ch., Koperkiewicz, A., 2016a. Alt-Wartenburg/Barczewko - Interdisziplinäre Erforschung einer spätmittelalterlichen Stadtwüstung im Ermland (Nordostpolen). Zeitschrift für Archäologie des Mittelalters, 44, 115-148.

Biermann, F., Herrmann, Ch., Koperkiewicz, A., 2016b. Alt Wartenburg/Barczewko na Warmii. Początki miasta średniowiecznego i jego fortyfikacje. In: Kobyliński, Z., ed. Archeologia Hereditas 7, Grodziska Warmii i Mazur 2. Nowe badania i interpretacje. Warszawa: Fundacja Res Publica Muliethnica, 49-77.

Biermann, F., Herrmann, Ch., Koperkiewicz, A., 2018a. Small Town in Great Wilderness Research into the former medieval town and castle of Alt-Wartenburg (Barczewko, North-Eastern Poland). In: Engberg, N., Etting, V., Meldgaard Sass Jensen, L., Sørensen, C., Wille-Jørgensen, D., eds. Building a Castle - Preparing for War or keeping the Peace? Castella Maris Baltici XIII / Castles of the North II. Bonn: Verlag Dr. Rudolf Habelt, 123-134.

Biermann, F., Herrmann, Ch., Koperkiewicz, A., 2018b. Alt-Wartenburg im Kontext der spätmittelalterlichen Stadtgründungen im Ermland. In: Köster, G., Link, C., Lück, H., eds. Kulturelle Vernetzung in Europa. Das Magdeburger Recht und seine Städte. Dresden Sandstein Verlag, 403-422.
Von Bönigk, G., 1883. Die Stätte der alten Stadt Warteburg und die Wallberge der Umgebung. Altpreußische Monatsschrift, NF 20, 152-160.

Boockmann, H., 1981. Der Deutsche Orden. Zwölf Kapitel aus seiner Geschichte. München: C. H. Beck.

Brückner, M., 2016. Gräben und Keller - Hannovers Stadtbefestigung im Querschnitt. Archäologie in Deutschland, 5, 49.

Bugys, P., 2014. Šarvuotè Lietuvos Didžiojoje Kunigaikštystèje XIII a. antroje puséje - XVI a. viduryje (archeologijos duomenimis). (Daktaro disertacija). Klaipedos universitetas.

Dediala, R., 2018. Kariaunos samprata Lietuvos istoriografijoje: nuo archeologijos iki istorijos. Acta Historica Universitatis Klaipedensis, 37, 129-145.

Gudavičius, E., 1992. Lietuvių pašauktinès kariuomenès organizacijos bruožai. Karo archyvas, XIII, 34-118.

Gudavičius, E., 2001. Lietuvos istorija. Nuo seniausiu laiku iki 1569 metų. Vilnius: Lietuvos rašytojų sąjungos leidykla.

Heinrich von Lettland, 1959. Livländische Chronik / Chronicon Livoniae (Bauer, A., Bearb.) (=Ausgewählte Quellen zur Deutschen Geschichte des Mittelalters, Freiherr vom Stein-Gedächtnisausgabe, XXIV). Darmstadt: Wissenschaftliche Buchgesellschaft.

Herrmann, Ch., 2015. Burgen im Ordensland Preußen. Handbuch zu den Deutschordens- und Bischofsburgen in Ost- und Westpreußen. Petersberg: Michael Imhof Verlag.

Housley, N. 1992. The later Crusades, 1274-1580. From Lyons to Alcazar. Oxford University Press.

Ivinskis, Z., 1978. Lietuvos istorija. Iki Vytauto Didžiojo mirties, Roma: Lietuvių katalikų mokslo akademija.

Kazakevičius, V., 1998. Geležies amžiaus baltu genčiu ginkluotè. (Habilitacinis darbas). Vilnius.

Klimek, R., 2008. Terra Gunelauke. Przewodnik archeologiczny. Diwity: Stowarzyszenie "Nasze Gady". 
Klimek, R., 2013. Zaginione zamki i strażnice pośwadczone w źródłach z pierwszej połowy XIV wieku z obszaru Warmii biskupiej oraz propozycje ustalenia ich lokalizacji. In: Kobyliński, Z., ed. Grodziska Warmii i Mazur 1. Stan wiedzy i perspektywy badawcze. Archeologia Hereditas 2. Warszawa: Uniwersitet Kardynała Stefana Wyszyńskiego, 205-224.

Kulikauskienė, R., 1972. Maišiagalos piliakalnio tyrinejjimai $1971 \mathrm{~m}$. Archeologiniai ir etnografiniai tyrinejimai Lietuvoje, 1970 ir 1971 metais, 22-25.

Kulikauskienè, R., 1974. Maišiagalos piliakalnio tyrinejjimai 1972 ir 1973 m. Archeologiniai ir etnografiniai tyrinejimai Lietuvoje, 1972 ir 1973 metais, 23-29.

Kuncevičius, A., 2005. Lietuvos viduramžių archeologija. Vilnius: Versus aureus.

Merkevičius, A., 2005. Karyba Lietuvos teritorijoje žalvario amžiuje. Karo archyvas, XX, 8-49.

Michelbertas, M., Vitkūnas, M., 2003. Baltų karybos senajame geležies amžiuje bruožai. Karo archyvas, XVIII, 8-64.

Nadolski, A., ed., 1985. Plemięta. Średniowieczny gródek w Ziemi Chełmińskiej (=Prace Archeologiczne 7, Towarzystwo Naukowe w Toruniu). Warszawa: Państwowe wydawnictwo naukowe.

Napierała, A., 2019. Pociski broni miotajacej $z$ badań archeologicznych $w$ Barczewku. (Unpublished MA-thesis). Gdańsk University.

Nikžentaitis, A., 1992. XIII-XV a. lietuvių kariuomenės bruožai (organizacija, taktika, papročiai). Karo archyvas, XIII, 3-33.

Nowakowski, A., 1994. Arms and armours in the medieval Teutonic Order's state in Prussia. Łódź: Oficyna Naukowa MS.

Paravicini, W., 1989/1995. Die Preußenreisen des europäischen Adels 1, 2. Beihefte Francia 17, Sigmaringen 1989/1995.

Petrauskas, G., 2017. Laidosena viduramžių Lietuvoje: mirusiuju deginimo paprotys. (Daktaro disertacija). Vilniaus universitetas.

Pósán, L., 2014. Ritterkultur im spätmittelalterlichen Litauen. In: Bárány, A., Orosz, I., Papp, K.,
Vinkler, B., eds. Müveltség és társadalmi szerepek: arisztokraták Magyarországon és Európában, Speculum Historiae Debreceniense 18. Debrecen: Debreceni Egyetem Történelmi Intézete, 51-58.

Rackevičius, G., 2002. Arbaletas ir lankas Lietuvoje XIII-XVI a. Vilnius: Pilių tyrimo centras „Lietuvos pilys".

Raczyński, E., ed. 1842, Puścizna po Janie Długoszu dziejopisie polskim, to jest: Kronika Wiganda z Marburga rycerza i kapłana Zakonu Krzyżackiego na wezwanie Długosza z rymowanej kroniki niemieckiej na język łaciński przetłomaczona. Poznań: Księgarnia Nowa.

Rieger, D., 2010. Platea Finalis. Forschungen zur Braunschweiger Altstadt im Mittelalter. (=Beiträge zur Archäologie in Niedersachsen, 15). Rahden: Verlag Marie Leidorf.

Riemann, E., 1965. Wortgeographie und Besiedlungsgeschichte Altpreußens. Jahrbuch des Vereins für Niederdeutsche Sprachforschung, 88, 72-106.

Röhrich, V., 1916. Die Kolonisation des Ermlands. Zeitschrift für die Geschichte und Altertumskunde des Ermlands, 19 (1-3). Braunsberg: Kommissionsverlag von Benders Buchhandlung, 173-306.

Rosmanitz, H., 2009. Burgenforschung im Spessart. Das „Alte Schloss“ in Kleinwallstadt. Beiträge zur Archäologie in Unterfranken 2009 (=Mainfränkische Studien Bd. 77). Büchenbach: Dr. Faustus, 243-286.

Rowell, S. Ch., 1994. Lithuania Ascending. A Pagan Empire within East-Central Europe, 1295-1345. Cambridge University Press.

Schütz, A., 2007. Die hoch- und spätmittelalterlichen Burgen und Adelssitze in der Uckermark, Land Brandenburg. Bestandsaufnahme und vergleichende Untersuchungen vom späten 12. bis zum 15. Jahrhundert. Berlin: Internetpublikation.

Scriptores, 1861. Hirsch, T., Töppen, M., Strehlke, E., Hrsg. Scriptores rerum Prussicarum. Die Geschichtsquellen der preussischen Vorzeit bis zum Untergange der Ordensherrschaft, I. Leipzig: Verlag von S. Hirzel. 
Scriptores, 1863. Hirsch, T., Töppen, M., Strehlke, E., Hrsg. Scriptores rerum Prussicarum. Die Geschichtsquellen der preußischen Vorzeit bis zum Untergange der Ordensherrschaft, II. Leipzig: Verlag von S. Hirzel.

Świętosławski, W., 2011. Uzbrojenie koczowników Wielkiego Stepu w czasach ekspansji Mongołów (XII$X I V$ w.). Wodzisław Śląski: Wydawnictwo Templum.

Szorc, A., 1990, Dominium warmiński 1243-1772. Olsztyn: Pojezierze.

Tautavičius, A., 2001. Seniausia praeitis. In: Girininkienè, V., ed. Veliuona (Jurbarko rajonas). Kaunas: Spindulys, 63-77.

Trupinda, J., 2009. Der Deutschordensstaat in Preußen. In: Jackiewicz-Garniec, M., Garniec, M., eds. Burgen im Deutschordensstaat Preußen. Pomesanien, Oberland, Ermland, Masuren. Olsztyn: Arta, 9-26.

Ubis, E., 2018. Archaeological Data as Evidence of Cultural Interaction between the Teutonic Order and Local Communities: Problems and Perspectives. Archaeologia Baltica, 25, 164-176.
Urbonaité-Ube, M., 2018. Stoneware from the $14^{\text {th }}$ to the $17^{\text {th }}$ Centuries Found in Archaeological Excavations in Vilnius. Archaeologia Baltica, 25, 191-202.

Vaičenonis, J., 2011. Lietuvos karyba: nuo baltų iki XXI amžiaus: kariuomenè, fortifikacija, mūšiai ir karvedžiai. Kaunas: Šviesa.

Vitkūnas, M., 2011. Kada lietuviai pradejjo kautis raiti? Lituanistica, 57 (1), 54-65.

Vitkūnas, M., Zabiela, G., 2017. Baltic hillforts: unknown heritage. Vilnius: Society of the Lithuanian Archaeology.

Voigt, J., 1832. Geschichte Preussens von den ältesten Zeiten bis zum Untergange der Herrschaft des Deutschen Ordens. Königsberg: Verlage der Gebrüder Borntraeger.

Медведев, А.Ф., 1966. Ручное метательное оружие (Лук и стрель, самострел). VIII-XIV вв. (=Археология СССР. Свод археологических источников, E1-36). Москва: Наука.

\section{LIEPSNOJANTIS ALT VARTENBURGAS - ARCHEOLOGINIAI DUOMENYS APIE KARINI VOKIEČIŲ ORDINO IR LIETUVOS DIDŽIOSIOS KUNIGAIKŠTYSTĖS KONFLIKTĄ IŠ APLEISTO VIDURAMŽIŲ MIESTO (DAB. BARCZEWKO, VARMIJA, LENKIJA)}

Felix Biermann, Christofer Herrmann, Arkadiusz Koperkiewicz, Edvinas Ubis

\section{Santrauka}

Straipsnyje nagrinejjama Lietuvos Didžiosios Kunigaikštystès ir Vokiečių ordino karo tikrovè. Siekiant ši karą įvertinti kitaip - neromantizuotai ir nepolitizuotai, pasitelkiami archeologiniai duomenys - materialieji įrodymai. Archeologiniai Alt Vartenburgo duomenys teikia naujų žinių apie 1354 m. Algirdo ir Kęstučio surengto žygio ị Prūsijos žemes pasekmes. Viduramžių miesto šalia dab. Barczewko miestelio (Lenkija) tyrimai yra Vokietijos ir Lenkijos 2013-2018 m. vykdyto mokslo projekto rezultatas.

XIV a. pagrindiniu karo veiksmu buvo tapę žygiai i priešininko teritoriją. Tyrimai Alt Vartenburgo gyvenvietėje atskleidè, kad čia yra gerai išlikę per ši antpuoli sunaikinto miesto reliktai: atidengta sudegusių namų liekanų, ginklų, aukų palaikų ir kitų radinių, liudijančių siaubimo ir smurto veiksmus. Taip pat pateikiamas istorinis kontekstas apie Vokiečiu 
ordino ir Lietuvos Didžiosios Kunigaikštijos karinio konflikto ir žygių pobūdị; ǐžvalgų apie karinę lietuvių taktiką bei ginkluotę.

Daugiausia dèmesio skiriama $1354 \mathrm{~m}$. Alt Vartenburgo miesto apgulties, užèmimo ir sunaikinimo rekonstrukcijai pagal archeologinius duomenis. Medžiaga igalina atkurti miesto užèmimo ir jo sunaikinimo eigą bei kraupų likimą. Ši rekonstrukcija yra bene pirmas toks detalus tyrimas apie to meto užimamų miestų likimą. Duomenys padeda suvokti ne tik bendrą karo vaizdą, bet ir atskirų miesto gyventojų žūties istoriją.

\section{ILIUSTRACIJŲ SĄRAŠAS}

1 pav. Apleistas Alt Vartenburgo (Barczewko) miestas. Vaizdas iš oro iš vakarų pusès su matomu pylimu ir 2018 m. tyrimų vietomis. L. Plitho Lauritseno nuotr.

2 pav. Apleistas Alt Vartenburgo (Barczewko) miestas. Skaitmeninis ekstrapoliuotas žemės paviršiaus modelis pagal LIDAR duomenis su viduramžių miesto ir jo aplinkos magnetometrinių tyrimų planais. P. Wroniecki nuotr.

3 pav. Apleistas Alt Vartenburgo (Barczewko) miestas. Prekyvietės šiaurinès ir vakarinès dalies $2014 \mathrm{~m}$. archeologinių tyrimų vieta su atidengtais rūsiais ir gaisro liekanomis. A. Koperkiewicziaus nuotr.

4 pav. Apleistas Alt Vartenburgo (Barczewko) miestas. Panorama nuo vakarinio gynybinio griovio (su matomu perkasos $1 / 14$ profiliu) ì lauką vakarinèje miesto pusèje - pagrindinè antpuolio vieta. F. Biermanno nuotr.

5 pav. XIV-XV a. valdos ir Lietuvos kariuomenès antpuolių vietos, minimos tekste: a) Vokiečių ordino valdomos žemès; b) Vyskupų valdomos žemès Prūsijoje ir Livonijoje; c) Lietuvos Didžiosios Kunigaikštijos valdomos žemès; d) Vokiečių ordino laikinai valdytos žemès; e) Alt Vartenburgas (Barczewko), užpultas 1354 m.; f) Antpuolių vietos ir mūšiai (metai): 1) Rastenburg (Kentšynas) 1345, 1347; 2) Rößel
(Rešlius) 1347, 1353; 3) Leunenburg (Sątoczno) 1347; 4) Gerdauen (Железнодорожный) 1347; 5) Insterburg (Черняховск) 1347; 6) Ragnit (Неман) 1347; 7) Allenstein (Olštynas) 1356; 8) Guttstadt (Dobre Miasto) 1356; 9) Johannisburg (Pisz) 1361; 10) Georgenburg (Маёвка) 1364; 11) Angerburg (Węgorzewo) 1365; 12) Nordenburg (Крылово) 1366; 13) Rudau (Мельниково). Ch. Herrmann ir E. Ubis sud.

6 pav. Apleistas Alt Vartenburgo (Barczewko) miestas. Geležinis kirtiklis su sudegusiu kotu ir statinès dangtis, aptikti rūsyje (objekte 158). A. Koperkiewicziaus nuotr.

7 pav. Apleistas Alt Vartenburgo (Barczewko) miestas. Bronzinis katilas su geležinèmis rankenèlèmis ir keraminiai indai aptikti ūkiniame pastate (objekte 234). F. Biermanno nuotr.

8 pav. Apleistas Alt Vartenburgo (Barczewko) miestas. Pirties pastato rūsys (objektas 224) su suvirtusiomis medinėmis konstrukcijomis ir keraminiais indais. F. Biermanno nuotr.

9 pav. Apleistas Alt Vartenburgo (Barczewko) miestas. Keraminiai indai, aptikti gaisro liekanose rūsyje (objekte 224). Tarp indų dažnas radinys glazūruoti beveik akmens masès indai. F. Biermanno nuotr.

10 pav. Apleistas Alt Vartenburgo (Barczewko) miestas. Pintinès fragmentai, aptikti rūsyje (objekte 566). F. Biermanno nuotr.

11 pav. Apleistas Alt Vartenburgo (Barczewko) miestas. Ištirtų plotų planas su pagrindinèmis struktūromis ir arbaleto, taip pat lanko strèlių antgalių radimvietėmis. A. Koperkiewicziaus ir $\mathrm{A}$. $\mathrm{Na}$ pierałos nuotr.

12 pav. Apleistas Alt Vartenburgo (Barczewko) miestas. Geležiniai arbaleto ir lanko strèlių antgaliai. A. Koperkiewicziaus nuotr.

13 pav. Apleistas Alt Vartenburgo (Barczewko) miestas. Geležinis Bauernwehr tipo peilis, bendras vaizdas ir detalès. J. Strobino nuotr.

14 pav. Apleistas Alt Vartenburgo (Barczewko) miestas. Du geležiniai ietigaliai. M. Pacholeco nuotr. 
15 pav. Apleistas Alt Vartenburgo (Barczewko) miestas. Žiedinių šarvų fragmentai (1) ir smulkus bronzinis žiedas (jaunos moters?), aptiktas rūsyje (objekte 576). J. Strobino nuotr.

16 pav. Apleistas Alt Vartenburgo (Barczewko) miestas. Priešais sudegusios pirties rūsio (objektas 224) ìjjimą tgriuvusi akmenų krosnis, medinès konstrukcijos ir sienų užpildas (molis). F. Biermanno nuotr.

17 pav. Apleistas Alt Vartenburgo (Barczewko) miestas. Rūsio (objektas 16) vaizdas nuo ieejimo pusès su mase gaisro liekanų. F. Biermanno nuotr.

18 pav. Apleistas Alt Vartenburgo (Barczewko) miestas. Sudegęs rūsys (objektas 566) su medinèmis sienų bei grindų konstrukcijomis ir moliu. F. Biermanno nuotr.

19 pav. Apleistas Alt Vartenburgo (Barczewko) miestas. Visiškai sudegęs rūsys (objektas 158), įvairių rakandų ir įrankių liekanos. A. Koperkiewicziaus nuotr.

20 pav. Apleistas Alt Vartenburgo (Barczewko) miestas. Rūsys (objektas 576) su sugriuvusiomis konstrukcijomis ir kaireje puseje aptiktais jaunos moters palaikais. A. Koperkiewicziaus nuotr.

21 pav. Apleistas Alt Vartenburgo (Barczewko) miestas. Žmogaus palaikai aptikti rūsyje po namo konstrukcijomis. A. Koperkiewicziaus nuotr.

22 pav. Apleistas Alt Vartenburgo (Barczewko) miestas. Žmogaus palaikai. A. Koperkiewicziaus nuotr.

23 pav. Apleistas Alt Vartenburgo (Barczewko) miestas. Rūsyje (objekte 162) - vaiko kaukolè, papuošalai ir geležinis įrankis. F. Biermanno nuotr.

24 pav. Apleistas Alt Vartenburgo (Barczewko) miestas. Artistinè Lietuvos kariuomenès antpuolio rekonstrukcija-piešinys, vaizdas iš vakarų pusès. L. Plith Lauritseno nuotr.

25 pav. Apleistas Alt Vartenburgo (Barczewko) miestas. Pagrindinès gatvès vaizdas užimant. Artistinè Lietuvos kariuomenès antpuolio rekonstrukcija-piešinys, vaizdas iš vakarų pusès. L. Plith Lauritseno nuotr. 